\title{
Coastal permafrost landscape development since the Late Pleistocene in the western Laptev Sea, Siberia
}

\author{
MARIA WINTERFELD, LUTZ SCHIRRMEISTER, MIKHAIL N. GRIGORIEV, VIKTOR V. KUNITSKY, ANDREI ANDREEV, \\ ANDREW MURRAY AND PIER PAUL OVERDUIN
}

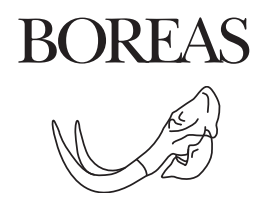

Winterfeld, M., Schirrmeister, L., Grigoriev, M. N., Kunitsky, V. V., Andreev, A., Murray, A. \& Overduin, P. P.
2011: Coastal permafrost landscape development since the Late Pleistocene in the western Laptev Sea, Siberia.
Boreas, 10.1111/j.1502-3885.2011.00203.x. ISSN 0300-9483.

The palaeoenvironmental development of the western Laptev Sea is understood primarily from investigations of exposed cliffs and surface sediment cores from the shelf. In 2005, a core transect was drilled between the Taymyr Peninsula and the Lena Delta, an area that was part of the westernmost region of the non-glaciated Beringian landmass during the late Quaternary. The transect of five cores, one terrestrial and four marine, taken near Cape Mamontov Klyk reached $12 \mathrm{~km}$ offshore and $77 \mathrm{~m}$ below sea level. A multiproxy approach combined cryolithological, sedimentological, geochronological $\left({ }^{14} \mathrm{C}-\mathrm{AMS}\right.$, OSL on quartz, IR-OSL on feldspars) and palaeoecological (pollen, diatoms) methods. Our interpretation of the proxies focuses on landscape history and the transition of terrestrial into subsea permafrost. Marine interglacial deposits overlain by relict terrestrial permafrost within the same offshore core were encountered in the western Laptev Sea. Moreover, the marine interglacial deposits lay unexpectedly deep at $64 \mathrm{~m}$ below modern sea level $12 \mathrm{~km}$ from the current coastline, while no marine deposits were encountered onshore. This implies that the position of the Eemian coastline presumably was similar to today's. The landscape reconstruction suggests Eemian coastal lagoons and thermokarst lakes, followed by Early to Middle Weichselian fluvially dominated terrestrial deposition. During the Late Weichselian, this fluvial landscape was transformed into a poorly drained accumulation plain, characterized by widespread and broad ice-wedge polygons. Finally, the shelf plain was flooded by the sea during the Holocene, resulting in the inundation and degradation of terrestrial permafrost and its transformation into subsea permafrost.

MariaWinterfeld (e-mail: Maria.Winterfeld@awi.de),Lutz Schirrmeister (e-mail: Lutz.Schirrmeister@awi.de) and Pier Paul Overduin (e-mail: Paul.Overduin@awi.de), Alfred Wegener Institute for Polar and Marine Research, Telegrafenberg A43,D-14473 Potsdam,Germany; Mikhail N.Grigoriev (e-mail: grigoriev@mpi.ysn.ru) and Viktor V. Kunitsky(e-mail: kunitsky@mpi.ysn.ru), Melnikov Permafrost Institute, Siberian Branch, Russian Academy of Sciences, 677010, Yakutsk, Russia; Andrei A. Andreev (e-mail: andrei.andreev@awi.de),University of Cologne,Institute of Geology and Mineralogy, Zuelpicher Strasse 49a, D-50674 Cologne, Germany; Andrew Murray (e-mail: anmu @ risoe.dtu.dk), Nordic Laboratory for Luminescence Dating, Department of Earth Sciences, University of Aarhus, Riso National Laboratory, DK 4000 Roskilde, Denmark; received 14th October 2009, accepted 15th December 2010.

Perennially frozen ground (permafrost) is a cold-climate phenomenon that is widespread in the Arctic and currently underlies about $25 \%$ of the land area of the Northern Hemisphere (Brown et al. 1998; Zhang et al. 1999). In the Siberian Arctic, permafrost is continuous and it is assumed to occur as relict permafrost beneath broad areas of the Siberian shelf seas (Fartyshev 1993; Romanovskii et al. 2004, 2005). Ice-bonded subsea permafrost on the continental shelves of the Laptev, East Siberian and Chukchi seas is usually inundated terrestrial permafrost that was formed when large portions of the non-glaciated shelves (Svendsen et al. 2004) were exposed to subaerial conditions by relatively lower sea levels during the last glacial cycle (Romanovskii et al. 1998; Romanovskii \& Hubberten 2001; Hubberten et al. 2004). The western Laptev Sea region, between the Taymyr Peninsula and the Lena Delta, represents the western edge of the non-glaciated Beringian landmass, where late Quaternary landscape evolution has been reconstructed using multi-proxy palaeoenvironmental records by Schirrmeister et al. (2008) and Müller et al. (2009) for the region studied in this paper. These studies describe several segments of landscape development of the late Quaternary history in the Eurasian Arctic based on sediment records of coastal cliffs and riverbanks. This method is limited to records above local water level and to accessible locations.

Our goal was to extend the late Quaternary palaeoenvironmental reconstruction below sea level and further into the past by including records of permafrost affected by marine transgression. This was achieved by using sediment cores drilled in 2005. Initial results dealt with the transition of terrestrial into subsea permafrost and the rate of degradation of subsea permafrost (Overduin et al. 2007b, 2008; Rachold et al. 2007). In this paper we present new results on the sedimentation history of the western Laptev Sea shelf and the landscape development of westernmost Beringia back to at least the Last Interglacial. We aim to improve the existing palaeogeographic understanding of the study region and the stratigraphic classification scheme and to highlight the interactions between terrestrial permafrost and the shallow marine environment.

\section{Geological and geographical setting}

The Laptev Sea is a shallow epicontinental sea bordered by the Taymyr Peninsula to the west and the New Siberian Islands to the east. Cape Mamontov Klyk $\left(\sim 73^{\circ} 60^{\prime} \mathrm{N}, 117^{\circ} 18^{\prime} \mathrm{E}\right)$ is situated about $150 \mathrm{~km}$ west of 


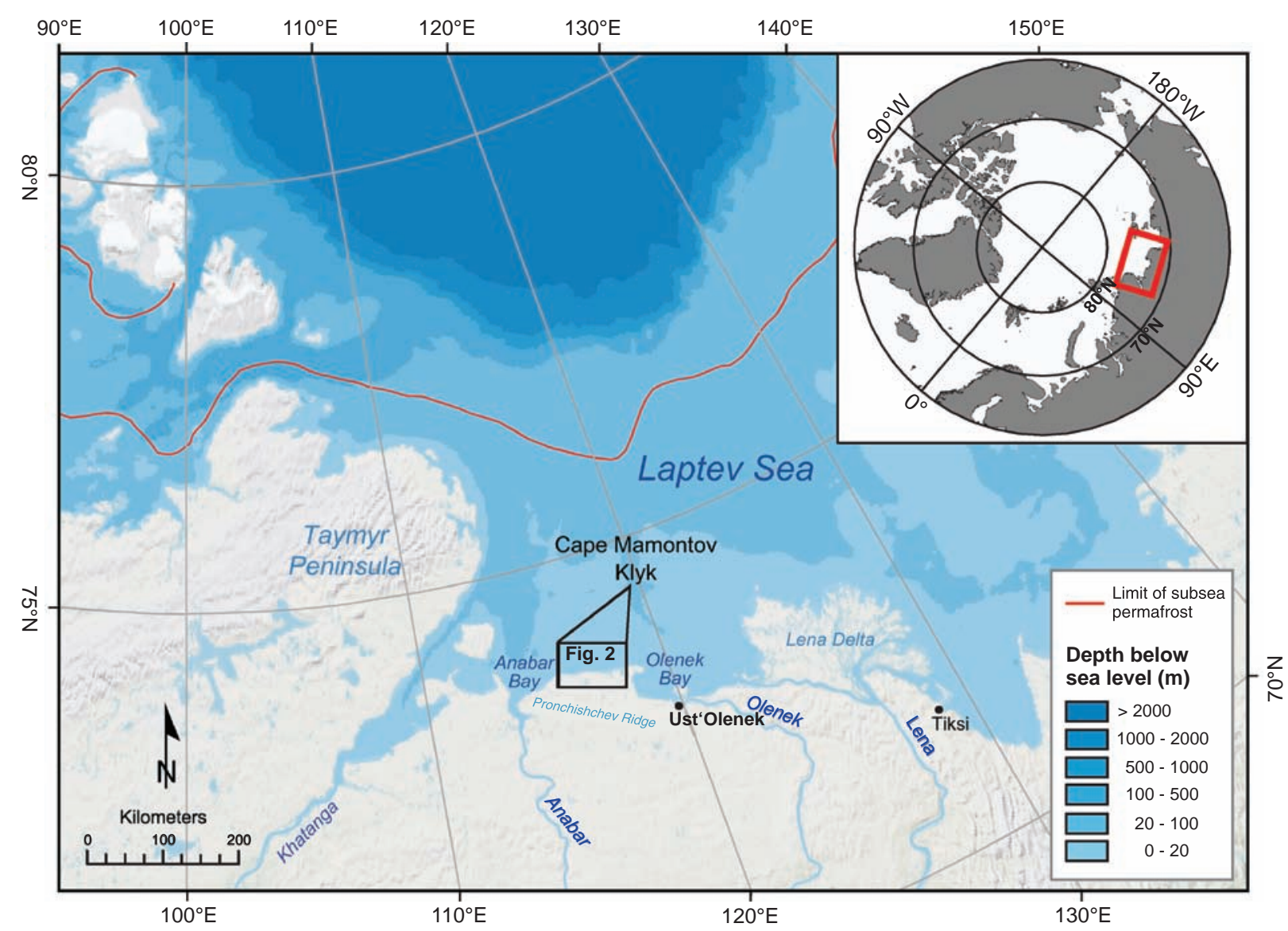

Fig. 1. Location of the study area in the western Beringian region.

the Lena Delta in the western Laptev Sea between the Anabar and Olenek rivers (Fig. 1). The coastal lowland north of Pronchishchev Ridge ( 270 m a.s.1.) is characterized by an undulating, gently sloping terrain with elevations between 25 and $35 \mathrm{~m}$ a.s.l., dipping slightly towards the north-northeast at angles between 0.1 and $0.2^{\circ}$ (Overduin et al. 2008; Schirrmeister et al. 2008). The bathymetry at the study site shows that the low dip angle continues offshore at less than $0.05^{\circ}$ for the next $13 \mathrm{~km}$ (Overduin et al. 2007a, 2008).

Owing to the low topographic gradient of the Laptev Sea shelf, average water depths are less than $60 \mathrm{~m}$. Sealevel changes during the past glacial cycle thus affected an area stretching 400 to $800 \mathrm{~km}$ north from the modern shoreline, out to approximately the modern 100-m isobath (Romanovskii et al. 2004). Consequently, the regression during the Late Pleistocene exposed large areas of the arctic continental shelf to severe climatic conditions, leading to permafrost formation and the development of distinctive geocryological features in the sediment. Geocryological features yield information on the conditions of their formation, including insights into the temperature and hydrological regime during and after deposition. Because the study region was not covered by ice sheets, at least during the
Weichselian glaciation (Svendsen et al. 2004), cold, thick and continuous permafrost formed on the exposed shelf and coastal plains with mean annual ground temperatures of -11 to $-12^{\circ} \mathrm{C}$, and with modelled permafrost thicknesses exceeding $400 \mathrm{~m}$ (Romanovskii et al. 2005).

Studies of the Quaternary geology of the western Laptev Sea region were carried out by Toll (1894), Chekanovsky (1896) and Tolmachev (1905) more than one hundred years ago. Toll (1894) interpreted the huge ice bodies in ice-rich sequences exposed along the sea coasts as buried glacial ice. Decades later, Boyarsky \& Mitt (1961) identified these ice bodies as large syngenetic ice wedges. Following geological surveys in the second half of the 20th century, the ice-rich deposits were controversially described as marine (Sochava 1933; Zhukov et al. 1968), fluvioglacial and fluviallacustrine (Puminov 1962), cryogenic-aeolian or fluviallacustrine (Kolpakov 1973) deposits. This ice-rich terrestrial permafrost coastline is eroded by a combination of erosion, abrasion and warming, at a current mean rate of about $4.5 \mathrm{~m} \mathrm{a}^{-1}$ for the area at Cape Mamontov Klyk (Grigoriev 2008). As a result of both coastal erosion and the Holocene sea-level rise between 11 and 5 cal. ka BP (Bauch et al. 2001), terrestrial permafrost 
has been inundated and degraded owing to the infiltration of seawater from above, warming at the sea bed and the influence of geothermal heat from below. The thickness of the thawed layer beneath the seabed grows with time, even at negative sea-floor temperatures, owing to the influx of heat and salt (Osterkamp 2001).

The geological basement of the study region belongs to the Lena-Anabar depression and is formed by the Olenek zone of the Late Mesozoic folded complexes, located at the border of the Siberian Craton and the Laptev Paraplatformal Block (Drachev et al. 1998). The main structural elements directly affecting the study area are the Upper Cretaceous to Cenozoic sedimentary cover (onshore including the Pronchishchev Ridge and shelf parts) and the Lena-Taymyr uplift zone (recent shelf part). The entire Laptev Sea region was, and continues to be, seismically active (Franke et al. 2004).

\section{Material and methods}

\section{Field studies}

In April 2005, five boreholes were drilled in the coastal region of Cape Mamontov Klyk along a north-south transect (along $117^{\circ} 10^{\prime} \mathrm{E}$ ) that reached from the mainland (core $\mathrm{C} 1$ ) to approximately $12 \mathrm{~km}$ offshore (cores C2 to C5; Fig. 2). The drilling was performed using a mobile drilling rig (URB-2A-2) with a hydraulic rotarypressure mechanism operating without drilling fluid. In order to preserve an undisturbed core lithology and to prevent seawater infiltration, well tubes and borehole casings of 1.5 to $4 \mathrm{~m}$ length and with diameters of between 70 and $160 \mathrm{~mm}$ were used. The withdrawn core material was cleaned and roughly characterized (frozen/ unfrozen, sediment and ice structures visible at the cleaned core surface). The material was packed in thermally insulated boxes and remained frozen during transport to Germany and further storage. Borehole temperatures were measured in all five boreholes 1 to 11 days after drilling using calibrated thermistors and have been published elsewhere (Junker et al. 2008; Overduin et al. 2008).

\section{Laboratory analyses}

Analyses included lithological and cryological core descriptions, and sedimentological, biogeochemical, palaeoecological, pore-water stable isotope and geochronological studies. Prior to laboratory analyses, the frozen core sections were halved lengthwise. A cleaned archive half was used for sediment and ice-structure descriptions and photographed. Sediment lithology was described based on colour changes, bedding structures, the occurrence of organic layers, and grain-size variations. Cryolithological observations classified and characterized ground ice (segregated ice lenses and veins) visible on the cleaned surface of the archive half. Ice textures were classified according to Katasonov (1983). Length and forms of characteristic structures were measured and described regarding their composition and inclusions. Lithostratigraphical classifications of different units were carried out by combining sediment properties, ice texture and colour.

The analytic half of the core was halved again into two quarters, one for microbiological (Koch et al. 2009) and one for geochemical, sedimentological and micropalaeontological analyses. This quarter was sectioned
Fig. 2. Borehole locations and the topography of the Cape Mamontov Klyk area (map produced by Guido Grosse, 2005).

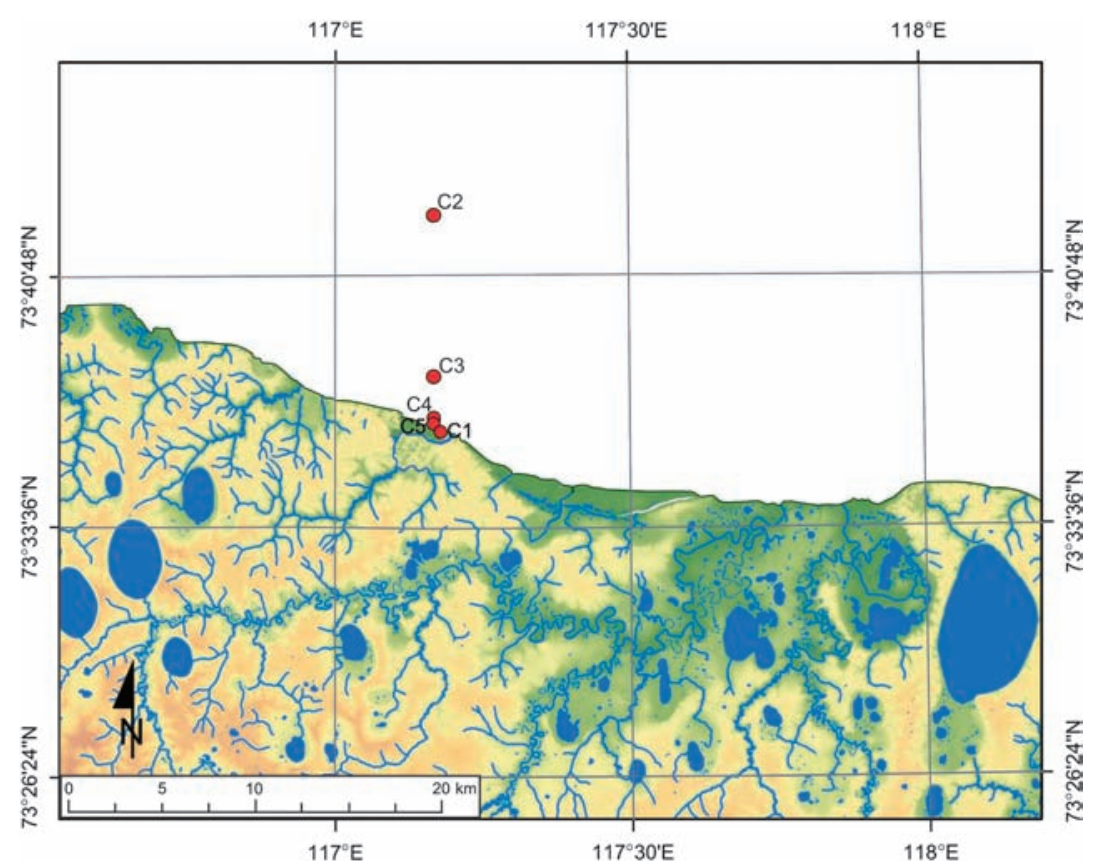


into appropriate samples that appeared homogenous on inspection and that varied from 2 to $20 \mathrm{~cm}$ in length. The samples were thawed and pore water extracted by means of Rhizons ${ }^{\mathrm{TM}}$ (membrane with $0.2-\mu \mathrm{m}$ pore diameter) for salinity measurements and further hydrochemical analyses. The drained sediment samples were freeze-dried for later sedimentological analyses.

After freeze-drying, the sediment samples were homogenized manually and then split into equal parts for the various analyses. The ice content was determined gravimetrically as the ratio of the mass difference between frozen and freeze-dried sample to the mass of the dry sample expressed as a percentage (van Everdingen 1998). The mass-specific magnetic susceptibility (MS) was measured with a MS meter (Bartington MS2) using the sensor type MS2B (values are expressed in SI units: $10^{-8} \mathrm{~m}^{3} \mathrm{~kg}^{-1}$ ). A portion of each sediment sample was treated with hydrogen peroxide in order to remove organic matter, and grain size was then measured using a Coulter LS 200 laser particle size analyser. The total carbon (TC), total organic carbon (TOC) and total nitrogen (TN) contents were determined with a CNS analyser (Elementar Vario EL III), and the TOC/TN $(\mathrm{C} / \mathrm{N})$ ratio was calculated. The stable carbon isotope composition of TOC was measured with a mass spectrometer (Finnigan DELTA S) after removal of carbonate with $10 \% \mathrm{HCl}$ and is reported as $\delta^{13} \mathrm{C}$ values in delta per mille notation $(\delta \%$ ) relative to the Vienna Pee Dee Belemnite (VPDB) Standard.

A total of 42 samples, each consisting of 1 or $2 \mathrm{~g}$ of the dry sediment taken from the cores, were prepared for pollen analysis using standard procedures (Faegri \& Iversen 1989). Lycopodium spore tablets were added to each sample in order to calculate total pollen and spore concentration. Pollen residues mounted in glycerin were analysed under a light microscope with a 400 to $1000 \times$ magnification.

\section{Dating}

For radiocarbon dating, both macroscopic plant remains and shells were taken from the freeze-dried sediment samples, and dating was performed using the accelerator mass spectrometry (AMS) facilities at the Leibniz Laboratory for Radiometric Dating and Stable Isotope Research in Kiel, Germany (for details see Nadeau et al. 1997, 1998). Radiocarbon ages are reported as conventional radiocarbon ages $( \pm 1 \sigma$ analytical error, Stuiver \& Polach, 1977) and are corrected for isotope fractionation occurring during sample formation and processing. In addition, selected core segments were separated during fieldwork for infrared optically stimulated luminescence (IR-OSL) dating on feldspar (Aitken 1998), performed at the Research Laboratory for Quaternary Geochronology in Tallinn, Estonia (e.g. Molodkov \& Bitinas 2006), and further samples were taken before core cutting in the laboratory for quartz optically stimulated luminescence (OSL) dating at Aarhus University's Nordic Laboratory for Luminescence Dating (Risø DTU, Roskilde, Denmark); for further information on sample treatment and analytical techniques, see Wintle (1997) and Murray \& Olley (2002).

\section{Results}

\section{Lithostratigraphy}

We classified the sediment into lithostratigraphical units I, II, III and IV, on the basis of their cryolithology, sediment and pore-water compositions, and stratigraphical order (Figs 3 to 5). The essential parameters that distinguish these four units are presented in Fig. 5. For clarity, we show these parameters for the longest cores $(\mathrm{C} 1, \mathrm{C} 2$, and $\mathrm{C} 3$ ) and their variations against depth. Data from cores $\mathrm{C} 4$ and $\mathrm{C} 5$ are included in Fig. 4.

Unit I. - The lowermost Unit I was observed only in core $\mathrm{C} 2$ from 77.0 to $64.7 \mathrm{~m}$ b.s.l. (below sea level) (Fig. $3 \mathrm{~A}$ ) and consisted of brownish to dark grey sandy-silts to silty fine-sands with horizontal lamination, several clayey layers, and single interbeds of more coarsely grained sand. Except for a small ice-bonded horizon at 72.4 to $71.0 \mathrm{~m}$ b.s.1., the cryostructure of Unit I was plastic-cryotic, which describes the ice-bearing but not totally ice-bonded state at negative temperatures. This largely ice-free state of the sediment results from the high pore-water salinity, ranging from 11.7 to $30.8 \%$, which depresses the freezing point, combined with temperatures of -1.0 to $-1.4^{\circ} \mathrm{C}$ at these depths. Under these conditions, clayey layers in particular behave plastically.

Unit I was further characterized by a mean grain size of $24 \mu \mathrm{m}$ (Fig. 4), with the coarsest (fine sand) sediment composition at the bottom, and particularly the silty grain-size fraction increasing from the bottom to the top of this unit (Fig. 5). The mass-specific MS had values mainly $>50$ SI. The TOC had mean values of around $0.7 \mathrm{wt} \%$, relatively low $\mathrm{C} / \mathrm{N}$ ratios (around 10 ), and $\delta^{13} \mathrm{C}$ values varying between -26.9 and $-24.3 \%$.

Unit II. - The subsequent Unit II was identified in all five cores, but over different depth ranges in each core. When taking core $\mathrm{C} 2$ as lower $(64.7 \mathrm{~m}$ b.s.1.) and core $\mathrm{C} 1$ as upper ( $\sim \mathrm{m}$ a.s.1.) boundaries, the sampled vertical thickness of this unit was almost $70 \mathrm{~m}$ (Fig. 3A). Unit II was composed largely of light grey and brownish grey fine sand to silty fine sand (mean grain size $96 \mu$ $\mathrm{m})$, mostly with horizontal bedding, with strongly varying proportions of silt and, to a minor extent, clay (Fig. 4). In addition, wood fragments, plant detritus interlayers and small peat inclusions were frequently observed (Fig. 6). Multiple upward gradations of coarse-grained to fine-grained sediments were observed 

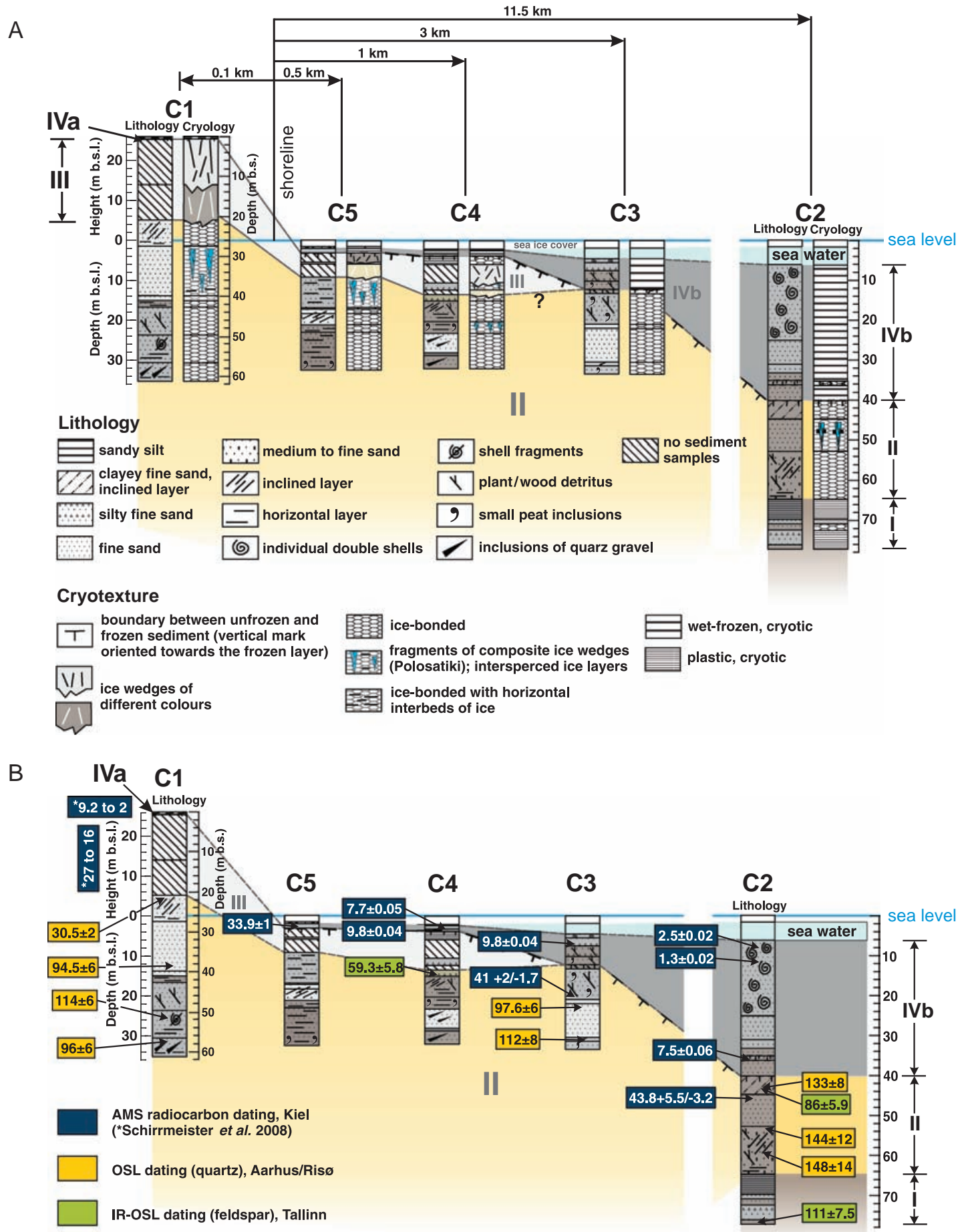

Fig. 3. A. Stratigraphical correlation of the core sequences $\mathrm{C} 1$ to $\mathrm{C} 5$ according to sedimentological and cryolithological characteristics. B. Overview of radiocarbon AMS, OSL and IR-OSL dates obtained for the coring transect (ages in ka).

within this unit. The finer sediments often contained ice structures indicative of subaerial conditions, such as blocky ice lenses (Fig. 6). The cryostructure was characterized mainly by pore ice cementing the sediment (gravimetric ice content $20-50 \mathrm{wt} \%$ ) and also showed typical features of terrestrial permafrost such as segre- gated ice lenses, ice veins bordering on wood fragments, and composite sand-ice wedges (Fig. 6).

The TOC content of this unit was generally very low $(<0.5 \mathrm{wt} \%)$. However, relatively high TOC peaks of 1.0 to $3.9 \mathrm{wt} \%$ were linked to layers containing twigs, wood fragments and plant detritus (e.g. $64.7-52.7 \mathrm{~m}$ b.s.1. in 

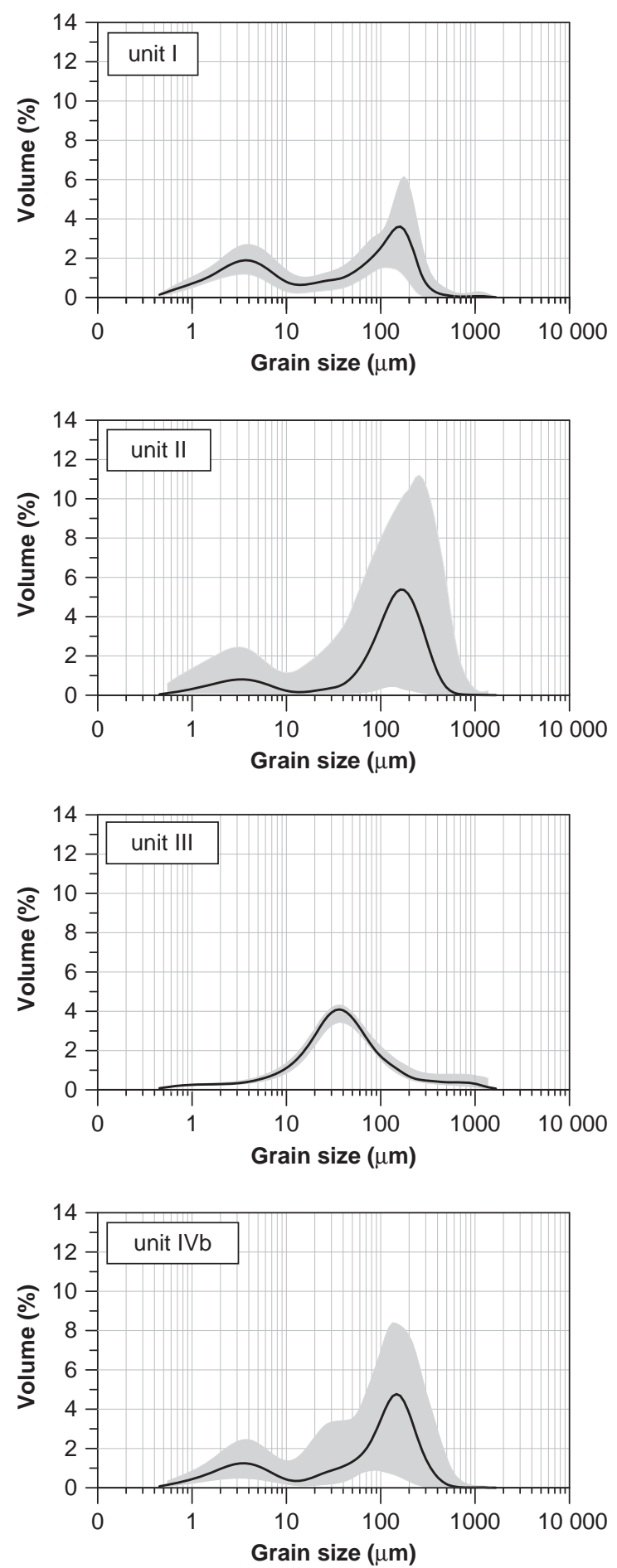

Fig. 4. Grain-size distribution curves of Units I, II, III and IVb (not presented are curves of Unit IVa, which are similar to those of Unit III and are found only in core C1). Unit I $n=7$, Unit II $n=90$, Unit III $n=17$, Unit IVb $n=20$.

core $\mathrm{C} 2$ ). The $\mathrm{C} / \mathrm{N}$ ratios had values of about 10 except for core $\mathrm{C} 2$. Here, the lower part of Unit II had C/N ratios of about 5 , followed by values of up to $20-30$ in the upper part (from $\sim 58.0 \mathrm{~m}$ b.s.l. upwards) (Fig. 5). The stable carbon isotope ratios ranged between -28.8 and
$-24.5 \%$. The MS values varied between 4 and 136 SI throughout the five cores, reflecting a rather heterogeneous sediment composition. Particularly in core $\mathrm{C} 2$, a transition from comparatively low values $(<40 \mathrm{SI})$ to higher values was observed at around $54 \mathrm{~m}$ b.s.l., which may point to changes in the sediment source area.

The overall sandy deposits of Unit II were frozen and mainly bonded by freshwater ice (salinity $<2 \%$ ), apart from transition layers to the underlying (Unit I in core $\mathrm{C} 2$ ) and overlying (Unit IVb in all offshore cores) units. Although the pore-water salinity of the terrestrial core $\mathrm{C} 1$ was generally lower than that in the marine cores, two distinct enrichments reaching values of $1-2 \%$ were observed between 60.8 and 50.0 and at around $40.0 \mathrm{~m}$ b.s.1.

Unit III. - Unit III covered about $20 \mathrm{~m}$ of the terrestrial core $\mathrm{C} 1$ and was completely positioned above sea level in that core (Fig. 3A). The two offshore cores closest to the coast (cores C4 and C5) also contained Unit III deposits, which were overlain by Unit IVb sediments.

Borehole positioning for core $\mathrm{C} 1$ produced an ice core with over $100 \mathrm{wt} \%$ ice ( $>80 \%$ ice by volume) for most of Unit III. As a result, no sediment samples were available for these depths (Fig. 5). Stratigraphically, Unit III corresponds to the Ice Complex of the Yedoma Suite, which formed during the Middle and Late Weichselian period and is widely distributed in the Laptev Sea region (e.g. Romanovskii 1993; Meyer et al. 2002; Schirrmeister et al. 2002, 2003, 2008; Sher et al. 2005). It is exposed at the coastal cliff, where it is composed of ice-rich, comparatively TOC-rich silts to sandy silts (Fig. 4) containing buried cryosols (Schirrmeister et al. 2008). The grain-size curves for Unit II show a distinct bimodal distribution centred around 2.5 and $110 \mu \mathrm{m}$, while Unit III is unimodal at $30 \mu \mathrm{m}$. The ice-wedge ice found in cores $\mathrm{C} 1, \mathrm{C} 4$ and $\mathrm{C} 5$ had salinities of less than $1 \%$ and was divided into two sections separated by a thin sediment layer. Both ice sections contained vertical stripes of brownish to grey silt and sand as well as gas bubbles.

Unit IVa. - This unit represents the terrestrial Holocene sediment cover and was exclusively observed in the uppermost $0.7 \mathrm{~m}$ of the terrestrial core $\mathrm{C} 1$ (Fig. 3A). It matches an up to 2-m-thick cover of cryoturbated peaty soil lying discordantly on top of the coastal cliffs (Schirrmeister et al. 2008). Similarly to Unit III, it was characterized by a silty grain-size composition (mean grain size $22 \mu \mathrm{m}$ ) and a comparatively high gravimetric ice content $(>50 \mathrm{wt} \%)$. Therefore, it is linked to a lenslike reticulated cryostructure that is characteristic of seasonal freezing and thawing of the ground (i.e. palaeo- and modern active layer). Furthermore, Unit IVa contained thick lenses of dark autochthonous peat (mean TOC $\sim 7.5 \mathrm{wt} \%$, mean $\mathrm{C} / \mathrm{N}$ ratio of 16 ).

Unit IVb. - Unit IVb was encountered in the upper parts of the offshore cores $\mathrm{C} 2$ to $\mathrm{C} 5$, showing an 

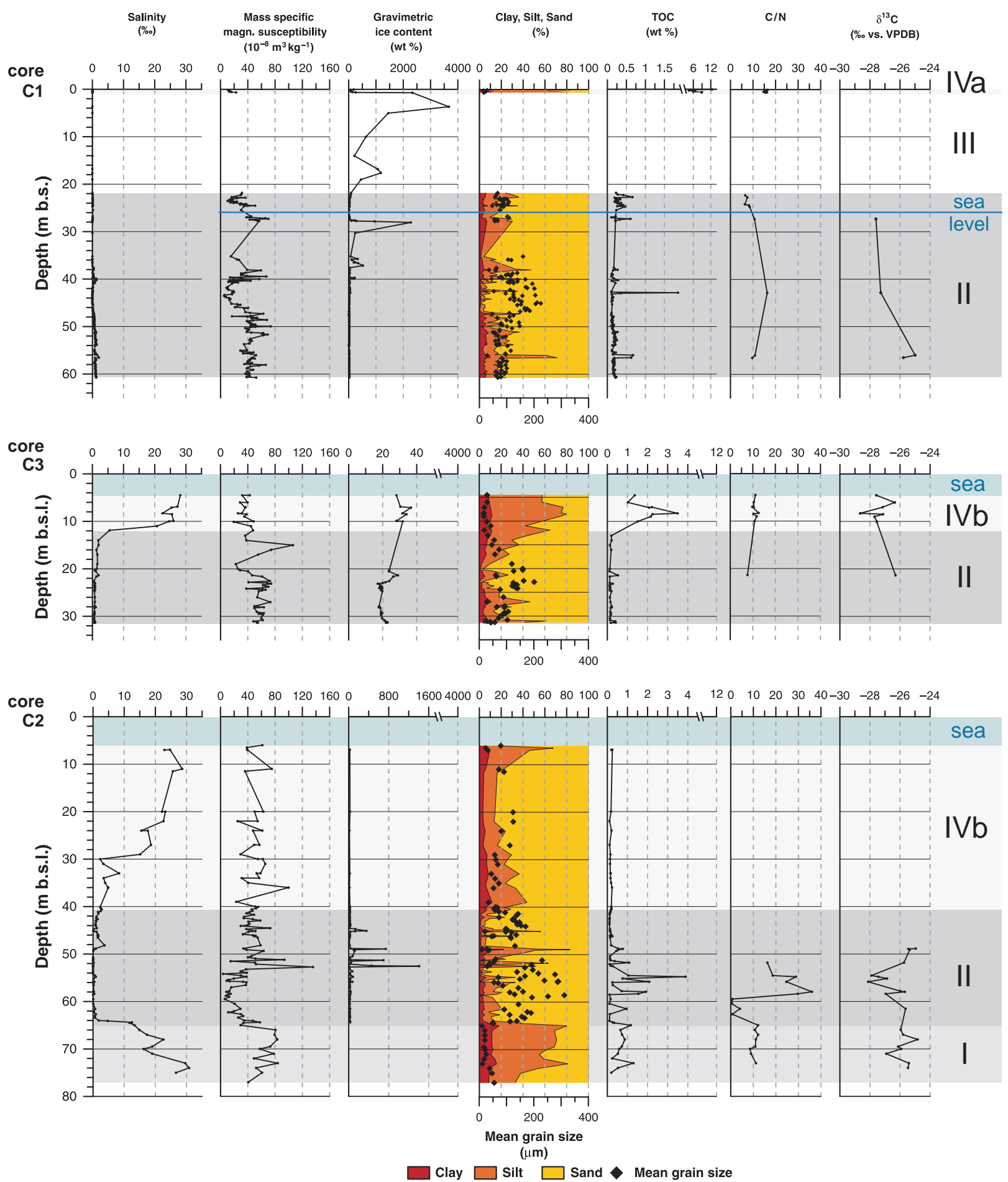

Fig. 5. Sediment properties of cores C1 (onshore) and C3 and C2 (offshore) plotted against depth. Depths are plotted relative to land surface for $\mathrm{C} 1$ and relative to sea level for $\mathrm{C} 3$ and $\mathrm{C} 2$. Stratigraphic units are indicated on the right.

increasing thickness further offshore (Fig. 3A). It consisted predominantly of a varying silty to fine sand composition (mean grain size $52 \mu \mathrm{m}$ ) and small portions of clay (Fig. 4). The grain-size distribution curve of Unit IVb shows three peaks in the fine-silt, coarse-silt and fine-sand fractions. In the uppermost $\sim 20 \mathrm{~m}$ of core $\mathrm{C} 2$ and $\sim 1 \mathrm{~m}$ of core $\mathrm{C} 3$, complete and fragmented bivalve shells were found. Fragments might have derived from eroded, reworked and re-deposited sediment (shell fragments), whereas complete shells suggest in situ living fauna. Specimens of Yoldia hyperborea (identification F. Riedel, Freie Universität Berlin), an infaunal bivalve inhabiting soft sediments in the North Atlantic and Arctic oceans (e.g. Stead \& Thompson 


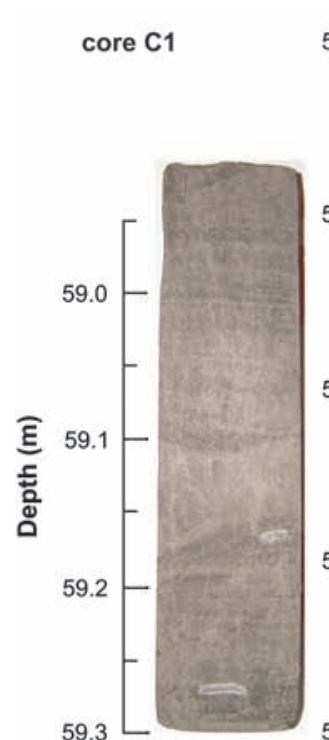

A

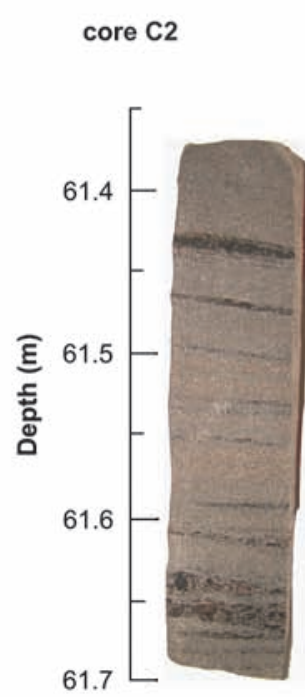

A

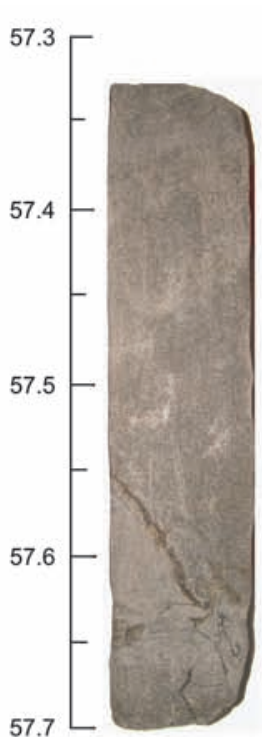

B

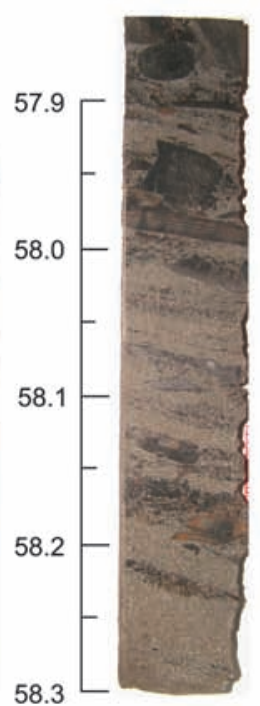

B

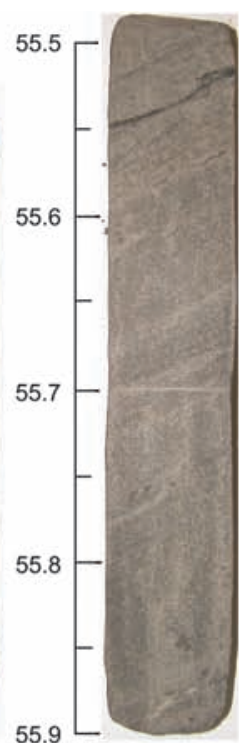

C

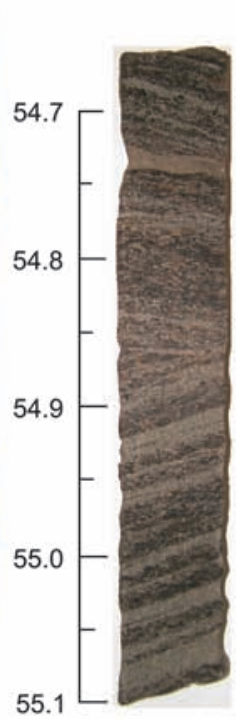

C

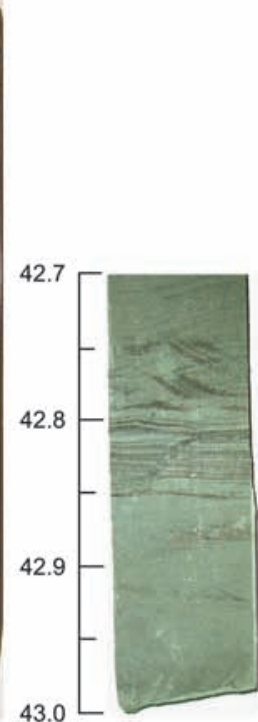

D

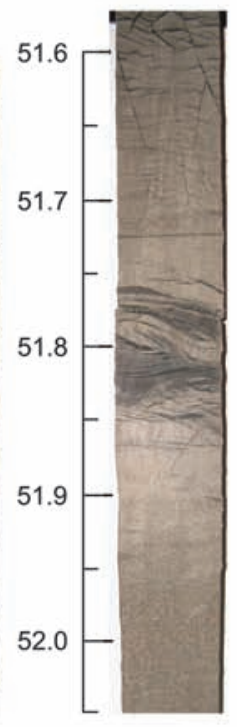

D

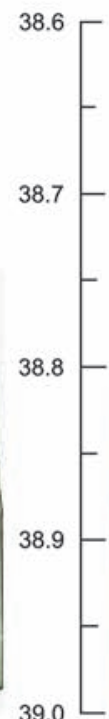

39.0

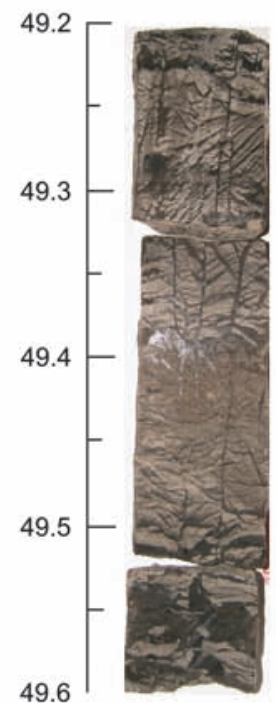

E

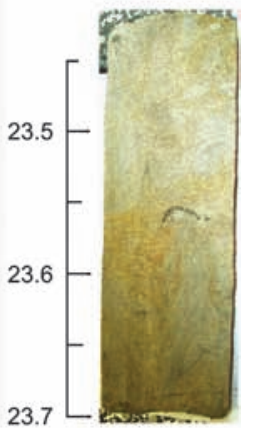

F

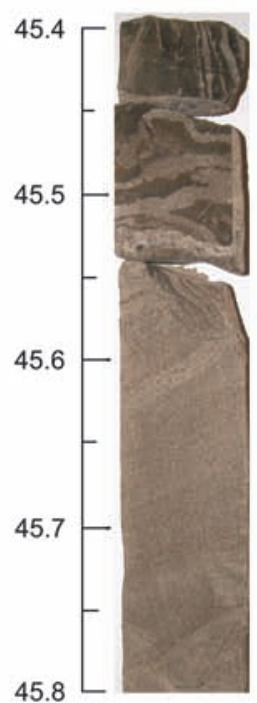

F

Fig. 6. Photography of Unit II deposits in the terrestrial core $\mathrm{C} 1$ and the submarine core $\mathrm{C} 2$ shows similar ice and sediment structures and demonstrates the terrestrial origin of currently submarine permafrost deposits. Core depths below the land (C1) or sea surface (C2) are indicated for each section. Core C1: A. Horizontally bedded sand with isolated quartz gravel $(\sim 3-4 \mathrm{~cm})$. B. Sand with diagonal ice veins. C. Regularly laminated, cross-bedded fine sand. D. Fine lamination with postdepositional ice veins. E. Ice lenses intersecting bedded sandy layers indicate a postdepositional freezing front that penetrated sands. F. Fine sand with plant fragments (grass roots). Core C2: A. Horizontally bedded sand with thin plant detritus laminae. B. Cross-bedded sand with large wood fragments (twigs). C. Alternating layers of sandy sediment and woody plant remains surrounded by segregation ice. D. At $51.8 \mathrm{~m}$, lattice-like, blocky ice lenses indicate frost-front penetration from above under subaerial conditions. E. Strongly blocky ice lenses indicate thawing and subsequent freezing of water/ice supersaturated sediment. F. Part of a composite sand-ice wedge.

2003), were found in Unit IVb (core C2), at depths of 7 and $11 \mathrm{~m}$ and were used for radiocarbon dating (Table 1). Shells or shell fragments were not observed in Unit IVb sediments of cores $\mathrm{C} 4$ and $\mathrm{C} 5$, but presumably existed before they were eroded. The MS values varied around $40 \mathrm{SI}$, with some exceptions of higher values of up to about 100 SI (Fig. 5). Generally, the TOC contents were low $(0.1$ to $0.2 \mathrm{wt} \%)$, but within the upper clearly silt- dominated part of core $\mathrm{C} 3$ and part of core $\mathrm{C} 4$ mean TOC values reached $2.0 \mathrm{wt} \%$ in contrast to values in the directly underlying frozen sands of Unit II. The $\mathrm{C} / \mathrm{N}$ ratios were around 10 and the $\delta^{13} \mathrm{C}$ ratios ranged from -28.6 to $-25.8 \%$ o (Fig. 5). The state of the sediment in the field was described as wet-frozen and cryotic, indicating deposits at negative temperatures that are not ice-bonded, as a result of high pore-water salinities. 
Table 1. Results of sediment dating. ${ }^{14} \mathrm{C}$ ages are reported as conventional radiocarbon ages $( \pm 1 \sigma$ analytical error) and corrected for isotope fractionation

\begin{tabular}{|c|c|c|c|c|c|c|c|c|}
\hline Unit & Environment & Sample & $\begin{array}{l}\text { Depth* } \\
\text { (m b.s.1.) }\end{array}$ & Core & ${ }^{14} \mathrm{C}$ AMS (a BP) & $\begin{array}{c}\text { OSL } \\
\text { (quartz) } \\
\text { (ka) }\end{array}$ & $\begin{array}{c}\text { IR-OSL } \\
\text { (feldspar) } \\
\text { (ka) }\end{array}$ & Lab. No \\
\hline $\mathrm{IVb}$ & Marine, interglacial & $\begin{array}{c}\text { C4 } 02.45 \\
\text { C4 } 03.70 \\
\text { C3 } 07.00 \\
\text { C2 } 11.00 \text { (shells) } \\
\text { C2 } 7.00 \text { (shells) } \\
\text { C2 } 36.0\end{array}$ & $\begin{array}{r}2.45 \\
3.7 \\
7.0 \\
11.0 \\
7.0 \\
36.0\end{array}$ & $\begin{array}{l}\mathrm{C} 4 \\
\mathrm{C} 4 \\
\mathrm{C} 3 \\
\mathrm{C} 2 \\
\mathrm{C} 2 \\
\mathrm{C} 2\end{array}$ & $\begin{array}{l}7705 \pm 55 \\
9770 \pm 45 \\
9810 \pm 40 \\
1290 \pm 25 \\
2555 \pm 25 \\
7570 \pm 60\end{array}$ & & & $\begin{array}{l}\text { KIA33187 } \\
\text { KIA33185 } \\
\text { KIA33186 } \\
\text { KIA33190 } \\
\text { KIA33191 } \\
\text { KIA33189 }\end{array}$ \\
\hline IVa & Terrestrial, interglacial & $\begin{array}{r}\text { Schirrmeister } \\
\text { et al. }(2008)\end{array}$ & & & $\begin{array}{l}9480 \pm 40 \\
\text { to } 2175 \pm 25\end{array}$ & & & \\
\hline III & Ice Complex, glacial & $\begin{array}{l}\text { Schirrmeister } \\
\text { et al. }(2008) \\
\text { C5 } 01.75\end{array}$ & 1.75 & C5 & $\begin{array}{l}27220 \pm 310 /-300 \\
\text { to } 14545 \pm 50 \\
33884+1150 /-1000\end{array}$ & & & KIA33188 \\
\hline II & Terrestrial, glacial & $\begin{aligned} & \text { C1 } 22.48-22.65 \\
& \text { C3 } 20.0 \\
& \text { C4 } 15.50 \\
& \text { C3 } 23.20-23.35 \\
& \text { C3 } 30.30-30.90 \\
& \text { C1 } 139.17-39.27 \\
& \text { C1 } 50.10-50.25 \\
& \text { C1 } 58.84-58.94 \\
& \text { C2 } 43.38-43.50 \\
& \text { C2 } 44.50-44.60 \\
& \text { C2 } 44.70-44.80 \\
& \text { C2 } 53.03-53.40 \\
& \text { C2 } 59.20-59.37\end{aligned}$ & $\begin{array}{l}22.6^{*} \\
20.0 \\
15.45 \\
23.3 \\
30.5 \\
39.2^{*} \\
50.2^{*} \\
58.9^{*} \\
43.4 \\
44.5 \\
44.7 \\
53.2 \\
59.3\end{array}$ & $\begin{array}{l}\mathrm{C} 1 \\
\mathrm{C} 3 \\
\mathrm{C} 4 \\
\mathrm{C} 3 \\
\mathrm{C} 3 \\
\mathrm{C} 1 \\
\mathrm{C} 1 \\
\mathrm{C} 1 \\
\mathrm{C} 2 \\
\mathrm{C} 2 \\
\mathrm{C} 2 \\
\mathrm{C} 2 \\
\mathrm{C} 2\end{array}$ & $41010+2110 /-1670$ & $\begin{array}{r}30.5 \pm 2.0 \\
\\
\\
97 \pm 6 \\
112 \pm 8 \\
94 \pm 6 \\
114 \pm 6 \\
96 \pm 6 \\
133 \pm 8 \\
\\
144 \pm 12 \\
148 \pm 14\end{array}$ & $59.3 \pm 5.8$ & $\begin{array}{c}\text { Risø } 075301 \\
\text { KIA33184 } \\
\text { RLQG 1729-026 } \\
\text { Risø } 075308 \\
\text { Risø } 075309 \\
\text { Risø } 075302 \\
\text { Risø } 075303 \\
\text { Risø } 075304 \\
\text { Risø 075305 } \\
\text { RLQG 1728-026 } \\
\text { KIA33192 } \\
\text { Risø } 075306 \\
\text { Risø } 075307\end{array}$ \\
\hline I & Lagoonal, interglacial & C2 77.0 & 77.0 & $\mathrm{C} 2$ & & & $111 \pm 7.5$ & RLQG 1726-026 \\
\hline
\end{tabular}

*Depths for the terrestrial core (C1) are given relative to the land surface (Fig. 3B).

\section{Sediment ages}

Sediment ages were determined by combining radiocarbon AMS analyses with OSL dating on quartz and feldspar in order to cover the entire expected age range and to obtain ages of sediment with only a few plant remains and low organic carbon contents. Table 1 and Fig. $3 \mathrm{~B}$ outline the dating methods, and the measured ages and uncertainties for all units and cores.

Sediment samples of the terrestrial core $(\mathrm{C} 1)$ were dated using OSL only (Fig. 3B). Samples from 58.9, 50.2 and $39.2 \mathrm{~m}$ below surface (b.s.) had ages of $96 \pm 6$, $114 \pm 8$ and $94 \pm 6 \mathrm{ka}$, respectively. Dating at $22.6 \mathrm{~m}$ b.s. yielded an age of $30.5 \pm 2 \mathrm{ka}$. These ages bracket the Unit II accumulation period. Owing to the ice-rich core material of Unit III in $\mathrm{C} 1$ (between $\sim 22.0$ and $\sim 3.7 \mathrm{mb}$ b.s.), no organic matter or sediment samples were available for age determination. However, radiocarbon AMS analyses from the study of the exposed nearby coastal cliff (Schirrmeister et al. 2008) showed an age sequence lasting from about 27.2 to $14.5 \mathrm{ka} \mathrm{BP}$ for Unit III.

Samples of core C2 were analysed with three different methods $\left({ }^{14} \mathrm{C}-\mathrm{AMS}\right.$, OSL and IR-OSL dating), which gave inconsistent results (Fig. 3B, Table 1). The feldspar IR-OSL determinations show ages of
$111.1 \pm 7.5 \mathrm{ka}$ at $77.0 \mathrm{~m}$ b.s.1. (Unit I) and of $86.2 \pm 5.9 \mathrm{ka}$ $\mathrm{BP}$ at $44.5 \mathrm{~m}$ b.s.1 (Unit II). In contrast, the OSL ages measured on quartz grains of Unit II deposits date back to $148 \pm 14 \mathrm{ka}(59.3 \mathrm{~m}$ b.s.1.), $144 \pm 12 \mathrm{ka}(53.0 \mathrm{~m}$ b.s.1.) and $133 \pm 8 \mathrm{ka}(43.4 \mathrm{mb}$ b.s.l.). The latter was a sample from slightly above the younger IR-OSL age. The radiocarbon dating of plant remains found in the upper section of Unit II between 44.7 and $44.8 \mathrm{~m}$ b.s.l. (composite icewedge horizon) gave a radiocarbon age of $43.8+5.5 /$ $-3.2 \mathrm{ka}$ BP. Shells of two samples from Unit IVb were radiocarbon dated to $1290 \pm 25 \mathrm{a} \mathrm{BP}$ at $11.0 \mathrm{~m}$ b.s.l. and to $2555 \pm 25$ a BP at $7.0 \mathrm{~m}$ b.s.l. (Fig. 3B, Table 1).

Two samples of core $\mathrm{C} 3$ that belong to Unit II were OSL dated to $112 \pm 8 \mathrm{ka}(30.5 \mathrm{mb}$ b.s.l.) and $97 \pm 6 \mathrm{ka}$ ( $23.3 \mathrm{~m}$ b.s.1.). One sample from this unit was radiocarbon dated to $41+2.1 /-1.7 \mathrm{ka}$ BP $(20.0 \mathrm{~m}$ b.s.1.). A second radiocarbon age was measured in the Unit IVb segment at $7.0 \mathrm{~m}$ b.s.l., giving $9770 \pm 45$ a BP.

Dating was also performed on samples from cores $\mathrm{C} 4$ and C5 (Table 1). IR-OSL dating on feldspar was performed on core $\mathrm{C} 4$ at $\sim 15.45 \mathrm{~m}$ b.s.l. (Unit II, $59.3 \pm 5.8 \mathrm{ka}$ ). Two samples from Unit IVb resulted in radiocarbon ages of $9812 \pm 41$ a $\mathrm{BP}$ at $3.7 \mathrm{mb}$ b.s.l. and $7705 \pm 55$ a $\mathrm{BP}$ at $\sim 2.45 \mathrm{~m}$ b.s.l. One sample from core C5 was dated and had a radiocarbon age of $33.8+1.2$ / $-1.0 \mathrm{ka}$ BP (1.75 m b.s.1., Unit III). 


\section{Micropalaeontological results}

Palynological analyses resulted in no pollen or too few pollen grains for palaeoenvironmental reconstructions for most of the studied 42 samples from the cores $\mathrm{C} 1$, $\mathrm{C} 2$ and C4. Only two samples, at $42.8-42.9$ and at $44.4-44.6 \mathrm{~m}$ b.s. in core $\mathrm{C} 1$, contained large amounts of well-preserved pollen. Samples from the lower deposits, between 47.86 and $60.56-60.67 \mathrm{~m}$ b.s., also contained some pollen grains. Pollen grains were also found in 14 samples in core C2, from 55.91 to $56.05 \mathrm{~m}$ b.s.l. and between 64.28 and $75 \mathrm{~m}$ b.s.l. Even for the majority of these samples, the pollen concentrations were very low (fewer than 1000 grains per gram), precluding synthesis of a pollen diagram. Nevertheless, pollen assemblages from these core segments can be used to characterize palaeoenvironmental conditions and are discussed below.

Pollen spectra of the two core $\mathrm{Cl}$ samples from 42.8-42.9 and 44.4-44.6 $\mathrm{m}$ b.s. were dominated by pollen of Alnus fruticosa, Betula nana and Ericales. The pollen concentration was also very high in these samples. Some freshwater indicators, such as pollen of Myriophyllum and remains of freshwater algae colonies (Botryococcus and Pediastrum), were present in these samples. The pollen assemblages of the pollen-bearing samples in lower $\mathrm{C} 1$ sediments also contained tree and shrub pollen taxa.

Relatively high contents and/or the permanent presence of tree and shrub pollen taxa (namely Pinus s/g Haploxylon, P. s/g Dyploxylon, Picea, Larix, Alnus fruticosa, Betula nana), the presence of pollen from some semi-shrub (Ericales, Rubus chamaemorus) taxa, and spores of Sphagnum characterized 14 samples from 55.91 to $56.05 \mathrm{~m}$ b.s.1. and between 64.28 and $75 \mathrm{~m}$ b.s.1. in core $\mathrm{C} 2$. The pollen concentration was significantly higher in the assemblages from 66 and $65 \mathrm{~m}$ b.s.1. (3300 and 8200 grains per gram respectively), where pollen of dwarf birches, shrub alder and Ericales reached their maxima (up to $16 \%, 18 \%$ and $7 \%$, respectively) in the studied spectra.

Complementary to pollen studies, Unit I of core C2 was checked for diatoms by Z. V. Pushina (VNIIO, St. Petersburg). Only a few fragments and single shells of marine (Hyalodiscus sp., Paralia sulcata, Porosira glacialis, Thalassiosira sp., Thalassiothrix longissima, Centralea ind.) and freshwater (Naicula radiosa, Eunotia praerupta, Pinnularia gibba, Tetracyclus lacustris) species were identified, as well as some sponge spicula that indicate near-coastal brackish conditions.

\section{Discussion}

\section{Stratigraphical and facies interpretation}

Eemian Interglacial (Unit I). - The lowermost and oldest Unit I was encountered only in core C2 and is probably of marine origin, based on high pore-water salinities, its relatively fine grain-size composition, fos- sil diatom records and pore-water hydrochemistry. The salinity values within this unit (on average $20 \%$, but up to $30.8 \%$ ) are similar to those in the upper $\sim 20 \mathrm{~m}$ of Unit $\mathrm{IVb}$ in core $\mathrm{C} 2$ and in the upper $10 \mathrm{~m}$ of Unit $\mathrm{IVb}$ in core $\mathrm{C} 3$ (Fig. 5), which represent reworked and seawater-saturated marine sediments. Bottom-water salinities of the Laptev Sea generally are characterized by large interannual and also regional fluctuations and vary from $24 \%$ in shallow coastal areas to $34 \%$ in central shelf areas (Zhigarev 1997), depending on the amount of freshwater input by rivers, sea-ice melting and the thawing of coastal permafrost in the spring and summer season. Furthermore, saline frozen and unfrozen deposits (including unfrozen sediments at negative temperatures) of Pleistocene and Holocene age are widely distributed along the Russian Arctic coast (Brouchkov 2002). These sediments either were deposited within a fully marine, shallow-water or lagoon environment or were deposited under terrestrial conditions and subsequently influenced by seawater incursion. The distribution of salt solutions and related cryogenic features can be spatially heterogeneous within the sediment. As a consequence, layers with varying cryotic states (plastic-cryotic and ice-bonded) that depend on pore-water salinity can develop as observed in Unit I, which is indicative for a shallow-water nearshore environment characterized by sharp changes in sedimentation and freezing (Anisimova 1981; Brouchkov 2002). The pore waters of Unit I show a hydrochemical composition similar to that of seawater with high contents of sodium, magnesium and chloride (Winterfeld 2009) and not the elevated calcium and sulphur concentrations associated with continentaltype salinization (Brouchkov 2002). Furthermore, a relatively low-energy depositional setting is deduced for this sediment section, especially when compared with the overlying more coarse-grained Unit II. A shallow near-coastal sea basin or a thermokarst lagoon with moderate water depths is assumed as the depositional environment (Fig. 8A). Low $\mathrm{C} / \mathrm{N}$ and $\delta^{13} \mathrm{C}$ ratios suggest a predominantly aquatic source of organic matter but could also be explained by a mixture of degraded terrigenous and aquatic organic carbon (Meyers et al. 1995; Meyers \& Lallier-Vergés 1997).

The stratigraphic position of Unit I (the oldest section of the coring transect) and the unfortunately only fragmentary geochronological and palynological records point to an Eemian interglacial formation. The presence of tree and shrub pollen (pine, spruce, larch, birch, alder and heather) as well as of Sphagnum spores in this unit is indicative of interglacial environmental conditions during sediment accumulation. However, it is rather unlikely that pine and spruce grew in the study area, and their pollen was probably transported northwards by wind and water. As pollen records from the more eastern Dmitry Laptev Strait show, larch, alder and birch grew at these latitudes during the Eemian 


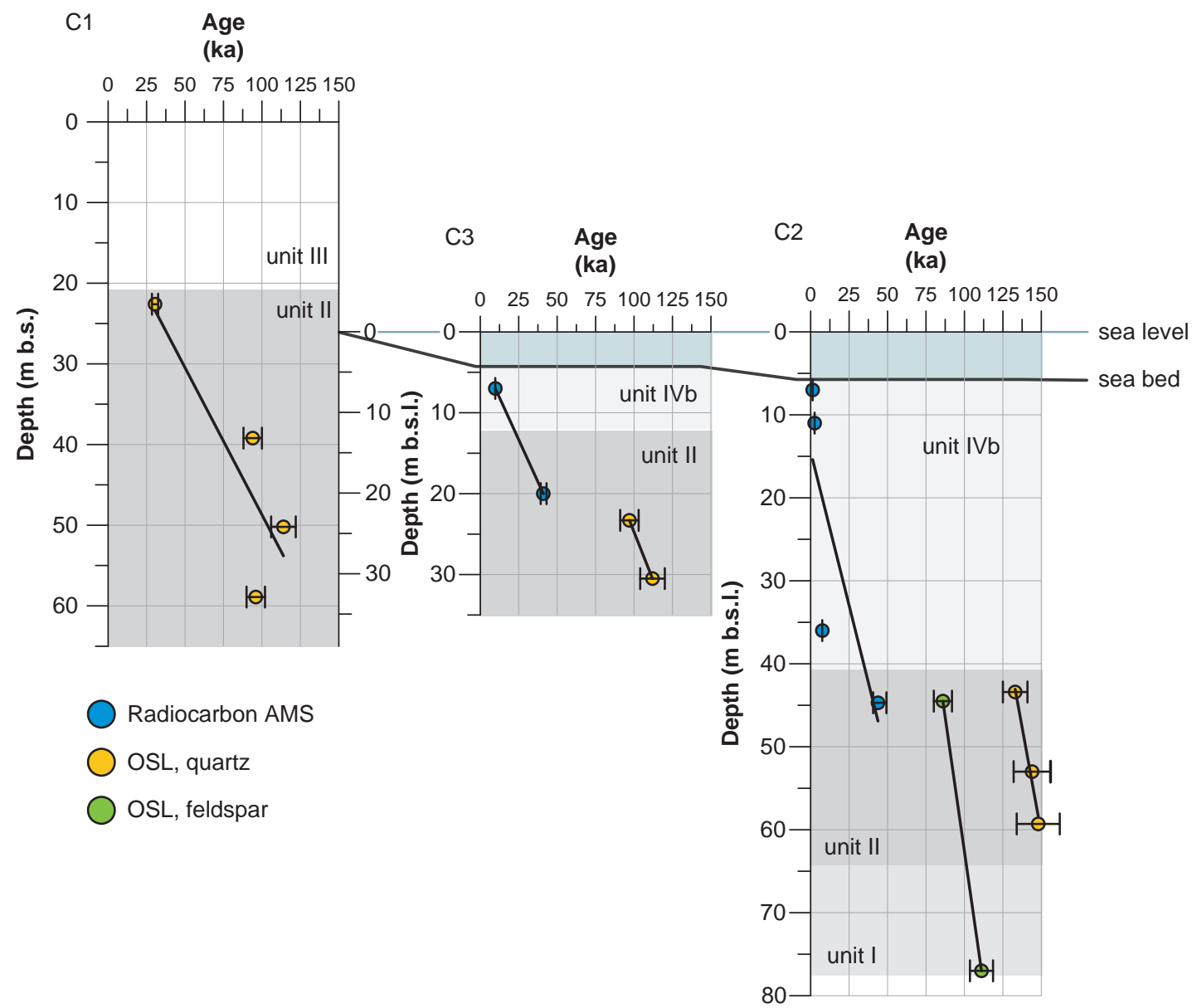

Fig. 7. Age-depth relationship for cores $\mathrm{C} 1, \mathrm{C} 2$ and $\mathrm{C} 3$ for the three geochronological methods applied. Linear trend lines show within-core correlations, and error bars indicate the laboratory-derived age uncertainties. Individual ages for C4 and C5 are shown in Fig. 3 , but do not provide a basis for an age-depth relationship. Depths are given in metres below the land surface $(\mathrm{C} 1)$ or sea level $(\mathrm{C} 2$ and $\mathrm{C} 3)$.

climatic optimum (e.g. Andreev et al. 2004; Ilyashuk et al. 2006; Wetterich et al. 2009) and hence could also have grown near the coring site. According to quantitative pollen-based climate reconstructions (Andreev et al. 2004), mean July air temperatures for the Laptev Sea region were at least $4-5^{\circ} \mathrm{C}$ warmer during the Eemian than they are today. The plant macrofossil-based estimation shows that summer temperatures might even have reached $10^{\circ} \mathrm{C}$ higher than today's (Kienast et al. 2008). The duration covered by these deposits was not defined with the ages measured. Possibly older (Late Saalian glaciation) OSL ages from the overlying Unit II in core $\mathrm{C} 2(133 \pm 8$ and $148 \pm 14 \mathrm{ka})$ imply a pre-Eemian time of deposition. However, that would also imply complete erosion of marine/lagoonal sediments of the last interglacial at this site, which are identified elsewhere on the Taymyr Peninsula south of the Byrranga Mountains (Svendsen et al., 2004). We suggest that uncertainties in the OSL dates permit an Eemian deposition (see section below).

The Eemian interglacial, from $\sim 130$ to $117 \mathrm{ka} \mathrm{BP}$, is associated with a relatively high global sea level of up to
$5 \mathrm{~m}$ above present (Chappell et al. 1996; Dumas et al. 2006), which implies complete inundation of the coring sites. Taking only the global sea level during the Eemian into account (i.e. disregarding isostasy), the altitudes of the sea floor at the study site should have lain in the range of 70 to $82 \mathrm{~m}$ b.s.l. The transgression would have reached slightly further inland than its modern position, consistent with our sedimentological and palaeoecological records. The low offshore elevation (i.e. the deep position below modern sea level) of the marine Eemian interglacial deposits in core $\mathrm{C} 2$ differs considerably from the position of comparable sediments found up to $100 \mathrm{~m}$ a.s.1. on the Taymyr Peninsula (Kind \& Leonov 1982; Svendsen et al. 2004) and from current ideas about altitudes of the Eemian transgression in Siberia (Bolshiyanov \& Molodkov 1999; Bolshiyanov 2006). It has not escaped our attention that the presence of non-marine interglacial sediments in core $\mathrm{C} 1$ (suggested by palynological data and OSL ages) and of marine interglacial sediments in core $\mathrm{C} 2$ suggests, when considered in the context of the IR-OSL ages, that the maximum extent of the associated transgression is 


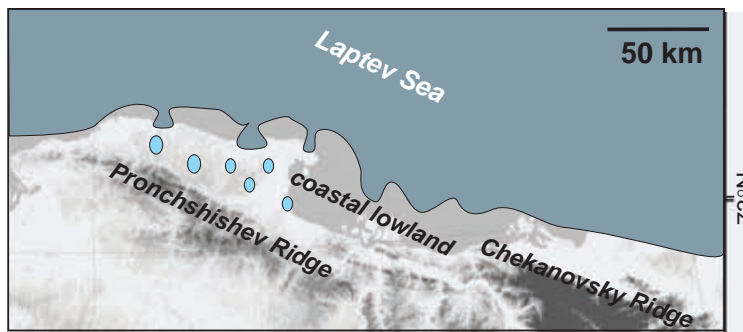

A Supposed Eemian lagoonal coastal lowland

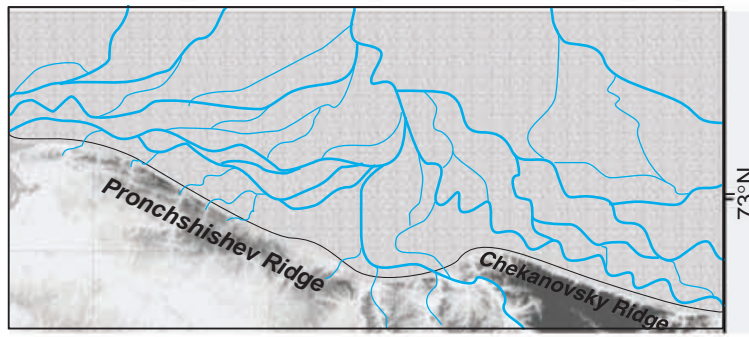

B Supposed Early to Middle Weichselian fluvial dominated terrestrial shelf

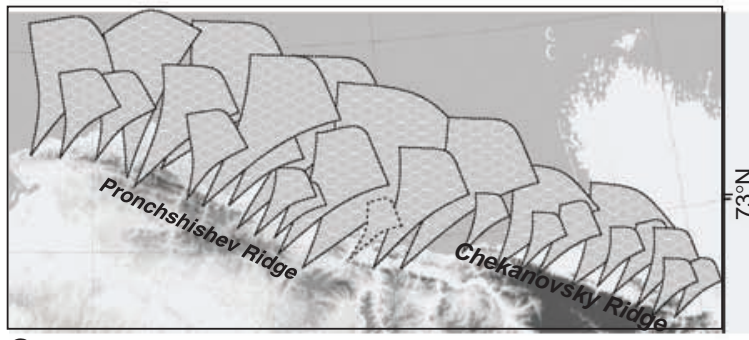

Supposed Late Weichselian flood plain area of Ice Complex accumulation

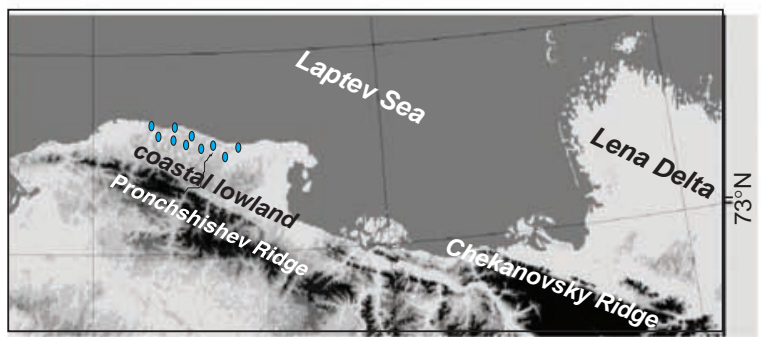

D Modern coastal lowland of the western Laptev Sea

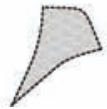

Debris fan with polygonal ice wedge systems
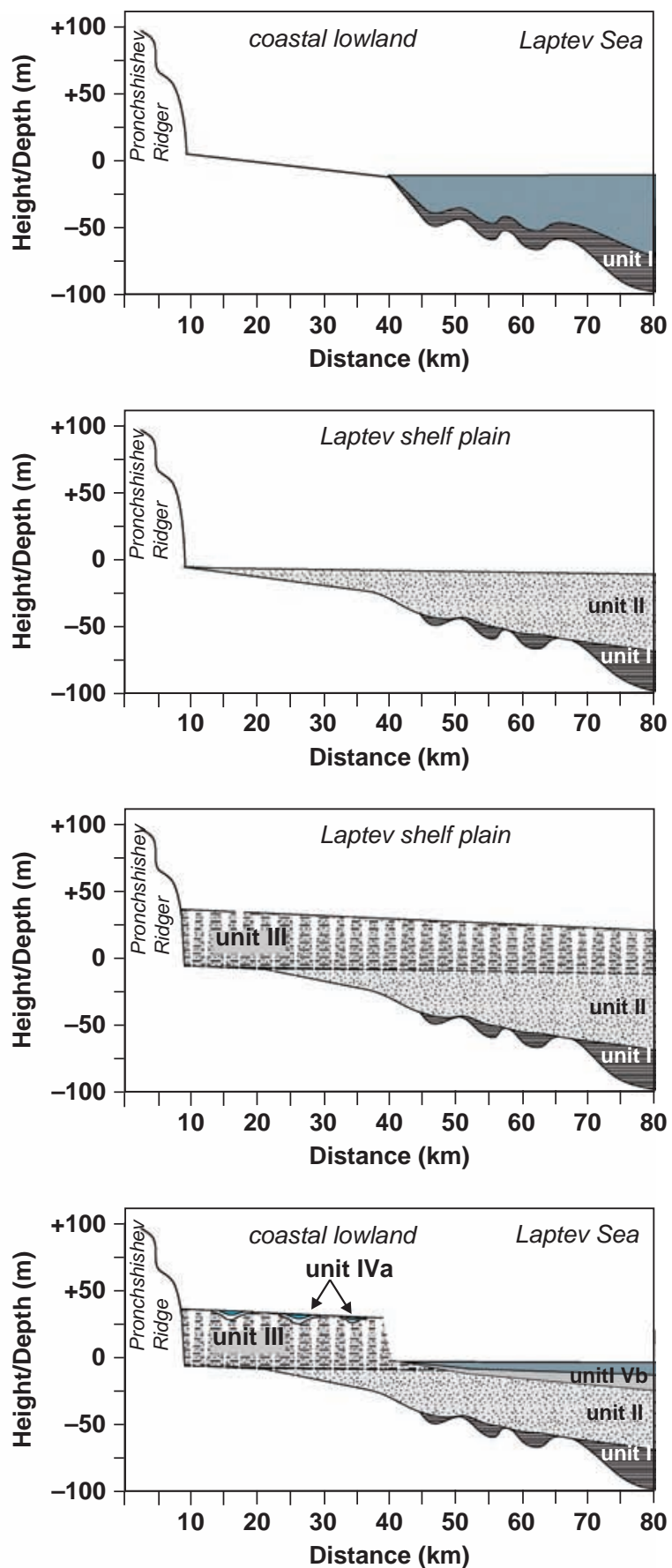

$\sqrt{ }$ Ice wedges

River branches of a braided river system

Fig. 8. Schematic representation of the interpreted regional landscape dynamics in the western Laptev Sea coastal region since the Eemian interglacial.

between the borehole positions of cores $\mathrm{C} 1$ and $\mathrm{C} 2$. Environmental changes resulting from sea-level fluctuation might have been accompanied by glacioisostatic adjustments in the study area after the deglaciation of the Late Saalian ice sheet, which still covered parts of the Taymyr Peninsula (Svendsen et al.
2004), and seismo-tectonic movement, which also occurs today at the eastern boundary of the Eurasian plate owing to rift-zone fracturing across the Laptev Sea (Drachev et al. 1998, 2003; Franke et al. 2004). An improved understanding of glacio- and seismo-tectonic processes in the western Laptev Sea is necessary to 
evaluate the current low-elevation position of Unit I and the likelihood of higher sea-floor altitudes during its accumulation.

Early to Middle Weichselian (Unit II). - Compared with the underlying and overlying stratigraphical units, Unit II consisted of coarser grain sizes (silty sands to fine sands), suggesting a more dynamic depositional environment, with some combination of terrestrial, fluvial and alluvial depositional environments, for example braided streams, accumulated during the Early to Middle Weichselian period between 110 and $30 \mathrm{ka}$ ago. We suggest that, as a result of glacial sea-level lowering, the Laptev Sea shelf drained and a wide lowland area was initially crossed by numerous river branches along with wide and flat river flood plains (Fig. $8 \mathrm{~B}$ ). Former thermokarst lagoons would have filled with sandy deposits and subsequently been covered by additional layers of sand. A braided to meandering river system characterized by migrating river channels is assumed as the principal depositional environment. This conclusion is based in particular on the observed sandy, alternate-bedded sediment structures containing layers of woody debris (Fig. 6). Unfortunately, no indicative fossils were found in these sand deposits that would allow more detailed palaeoecological reconstructions. However, an alternation between coarser grain-size compositions, associated with higher flow velocities from nival discharge events, and finer grain sizes, associated with reduced discharge and occasional stagnation, such as oxbow lakes, characterized this sediment sequence. The generally very low TOC contents of this unit $(<0.5 \mathrm{wt} \%)$ are consistent with the unfavourable conditions for plant growth and organic matter accumulation within a dynamic fluvial environment. Individual peaks in TOC content (up to $3.9 \mathrm{wt} \%$ ) and high $\mathrm{C} / \mathrm{N}$ ratios (20-30), particularly in core $\mathrm{C} 2$ between 48.8 and $61 \mathrm{~m}$, are linked to layers consisting of wood and twig fragments or peat showing a slightly inclined bedding, suggesting alluvial deposition along river banks. These occasional layers of accumulated organic detritus, and repeated evidence within the unit of frost penetration (subaerially) are strong evidence of migrating channels and the periodic relocation of stream beds.

Cryostructures common to all Unit II sediments, and prevalent in the cores $\mathrm{C} 2$ and $\mathrm{C} 1$, included fine sands bonded by texture ice containing composite sandice wedges and horizontal ice lenses. These features indicate that the sediment was affected by freezing front penetration and frost-cracking in a subaerial, terrestrial environment. These cryogenic features provide ample evidence for the terrestrial origin of the submarine permafrost deposits found below the bottom of the Laptev Sea in core C2 (Fig. 6). Schirrmeister et al. (2008) also concluded that the alternation of bedded sandy deposits and peaty sand exposed at the coastal cliff near Cape Mamontov Klyk was the result of fluvial and alluvial deposition by a discontinuous stream system. These deposits correspond to Unit II from the studied core transect.

Late Weichselian (Unit III). - We suggest that the fluvial landscape dominated by meandering river runoff gave way to a flat, swampy accumulation plain with low hydrological gradient, where ice wedge polygons characterized the micro-relief of the periglacial landscape (Fig. 8C). Fine-grained, poorly sorted and ice-rich deposits (i.e. Ice Complex) corresponding to Unit III were formed under moist, poorly drained surface conditions. Further sea-level lowering resulted in a northward shift of the coast, an increasing continentality of the climate, a drier climate and lower hydrological transport energy during the Last Glacial Maximum (LGM). Such a palaeolandscape assumption supports the ideas of a polygenetic formation of Ice Complex deposits as proposed by Sher et al. (2005). Similar stratigraphic sequences of sandy deposits covered by Ice Complex deposits have been described along the Olenyek Channel in the western Lena Delta (e.g. Wetterich et al. 2008), the Bykovsky Peninsula east of Tiksi (e.g. Siegert et al. 2002) and the coastal cliff near Cape Mamontov Klyk (Schirrmeister et al. 2008). Therefore, such sequences seem to be of at least regional stratigraphical relevance. The position of Unit III sediments below sea level in the cores $\mathrm{C} 4$ and $\mathrm{C} 5$ may have resulted from the infilling of a local depression with Ice Complex deposits. In contrast, the absence of Unit III in the cores C3 and $\mathrm{C} 2$ is supposed to be the consequence of the erosion of the relevant sediment section and/or of thawing of the sediment via warming and/or salt-water infiltration.

Holocene (Unit IV $a / b$ ). - Degradation of terrestrial permafrost occurred over a wide area in northern Siberia parallel to the Holocene transgressions of the Laptev Sea shelf (Bauch et al. 2001; Romanovskii et al. 2000). With the climate amelioration from the LGM to the early Holocene, permafrost degradation was initiated and led to the formation of abundant thermokarst depressions and other thermo-erosional landforms on the coastal plain (Grosse et al. 2006, Fig. 8D). Therefore, the Holocene onshore Unit IVa does not form a continuous sediment cover but rather occurs locally on top of the Ice Complex, where it fills small incipient and developed thermokarst depressions. Deposition in a terrestrial, low-energy Holocene environment, for example a polygonal tundra wetland (Schirrmeister et al. 2008), favourable for organic matter accumulation and the development of cryogenic soils is supported by the comparably high TOC contents (mean TOC $\sim 7.5 \mathrm{wt} \%, \mathrm{C} / \mathrm{N}$ ratio $\sim 16$ ) and the presence of abundant thick lenses of dark autochthonous peat and plant remains in the overall silty sediment. Unit IVa was characterized by a lens-like to network-like cryostructure as a result of seasonal 
thawing and freezing of the ground, which is typical for active-layer deposits. Similar deposits also mark the bottoms of thermokarst depressions and thermoerosional valleys.

The Holocene offshore Unit IVb was encountered in the uppermost parts of all marine cores ( $\mathrm{C} 2$ to $\mathrm{C} 5)$, with increasing thickness offshore as a result of increasing seawater influence. Although the sediment was cryotic (i.e. at negative temperatures), it remained unfrozen owing to high pore-water salinities that depressed the freezing point (Osterkamp 2001; Overduin et al. 2008). The sandy sediments of Unit IVb may be derived from two distinct stratigraphical units as a consequence of several interacting processes. First, Unit II material that thawed as a result of temperature and pore-watersalinity increases following the transgression was consequently subject to reworking by wave action. These sediments mixed with Unit III (Ice Complex) sediments that had been eroded, reworked and re-deposited as a result of coastal retreat. Wave action, sea-ice bulldozing and icerafting reworked material on the shallow shelf during the open-water season. In addition, material entrained in seaice during winter, and particularly in bottom-fast ice, could have been transported offshore. However, our data from Unit IVb do not provide a basis for distinguishing between the two sediment sources (Units II and III).

In the uppermost $\sim 20 \mathrm{~m}$ of core $\mathrm{C} 2$ and $1 \mathrm{~m}$ of core $\mathrm{C} 3$, fragments and complete bivalve shells were found, which might have derived from eroded, reworked and redeposited sediment (shell fragments) or, on the contrary, from in situ living marine fauna. Shells or shell fragments were not found within the wet-frozen sediments of cores $\mathrm{C} 4$ and $\mathrm{C} 5$, either because there was no living fauna or because erosion and sediment reworking through bottom-fast ice (for core C5) and ice bulldozing/rafting (for core $\mathrm{C} 4$ ) removed the respective deposits.

Currently, eroded Unit III (Ice Complex) material may be being re-deposited offshore. Ice Complex sediment TOC lies between 1 and $9 \mathrm{wt} \%$ and has a mean value of around $3 \mathrm{wt} \%$ at this location (Magens 2005; Schirrmeister et al. 2008), which matches the mean value of $2.6 \mathrm{wt} \%$ used by Zimov et al. (2006) for Ice Complex deposits. Traces of TOC were found in cores $\mathrm{C} 2$ and $\mathrm{C} 3$ at a greater distance from the modern coast, and only remnants were found in cores $\mathrm{C} 4$ and $\mathrm{C} 5$ near the coast. In core $\mathrm{C} 3$, Unit $\mathrm{IVb}$ contains a peak of $3.5 \mathrm{wt} \%$ TOC centred around $8 \mathrm{mb}$ b.s.1., probably reflecting the marine deposition of terrestrial organic material eroded from the coast. Further offshore, however, in core $\mathrm{C} 2$, Unit IVb has TOC values $<0.2 \mathrm{wt} \%$ throughout (Unit III, Fig. 5). In the period following erosion, eroded organic material is metabolized and/or transported further offshore in suspension rather than ending up in the sediment column. The fate of eroded material, including mineral, organic carbon, and water fluxes in the near-shore zone of the western Laptev Sea, depends on bathymetry, wave action, currents, and turnover rates. None of these parameters has been measured in the shallow-water $(<10 \mathrm{~m}$ depth $)$ region of the Laptev Sea shelf, making it difficult to estimate rates of sediment deposition, re-suspension, and transport.

In core $\mathrm{C} 3$, Unit IVb was characterized by a clearly silt-dominated grain-size distribution and a mean TOC content of $2.0 \mathrm{wt} \%$, in contrast to the directly underlying frozen sands of Unit II (Figs 4, 5). The combination of higher carbon and smaller grain size suggests a calmer depositional environment. According to bathymetric measurements performed in 2003 (Schirrmeister et al. 2004), core C3 was situated within a small-scale (hundreds of metres) depression where transport energy was reduced and silty grains from the suspension load accumulated. The slight depression might also represent the remnant of a flooded thermokarst lagoon acting as trap for fine-grained sediments and organic material (Romanovskii et al. 2000; Overduin et al. 2007b) that was eroded from the coast and not completely reworked and re-deposited when the coastal zone passed the location of core C3. Unit IVb deposits probably contain reworked material from the Ice Complex accumulated under marine conditions following the Holocene transgression that inundated the former periglacial landscape. Here, the Laptev Sea eroded and/or flooded the previously existing thermokarst landscape on the shelf plain (Fig. 8D). The numerous depressions and small valley systems were transformed into temporary lagoons and later filled and covered by marine deposits (Romanovskii et al. 2000).

\section{Chronostratigraphy}

The results of the three age-determination methods $\left({ }^{14} \mathrm{C}\right.$-AMS, IR-OSL, OSL dating) are inconsistent with each other within each core and between cores (Fig. 3B). When considered individually, each method produces internally consistent and plausible results. Two observed age reversals concern Holocene ages of marine shells in the uppermost part of core C2 (Table 1, Fig. 3B), which probably can be explained by the reworking and re-deposition of Unit IVb sediment by wave action and sea ice, and older OSL ages in the lowermost portion of core $\mathrm{C} 1$, which can almost be resolved by including uncertainties in the ages.

In core $\mathrm{C} 2$, a younger radiocarbon age $(\sim 44 \mathrm{ka} \mathrm{BP}$ at $44.7 \mathrm{~m}$ b.s.1.) lay below the OSL sample $(\sim 133 \mathrm{ka}$ $\mathrm{BP}$ at $43.4 \mathrm{~m}$ b.s.1.) and the IR-OSL sample ( $\sim 86.2 \mathrm{ka}$ at $44.5 \mathrm{~m}$ b.s.1.). The geocryological record indicates that permafrost formed after deposition, but there is no evidence of cryoturbation or sediment mixing sufficient to explain such age differences. A similar age difference exists between the radiocarbon $(41+2.1 /-1.7 \mathrm{ka}$ BP at $20.0 \mathrm{~m}$ b.s.1.) and the OSL ( $97 \pm 6 \mathrm{ka})$ dates in Unit II of core C3. We did not consider radiocarbon dates from Unit II in our interpretation, as they are not consistent 
with the Early Weichselian age of the unit's deposition. Nonetheless, a need to reconcile these ages with each other remains, as has been observed in other studies using OSL and radiocarbon dating methods in permafrost deposits, for example at the coastal cliff of Cape Mamontov Klyk (Schirrmeister et al. 2008).

In addition, there seem to be systematic age differences between OSL dating methods. For example, quartz OSL and feldspar IR-OSL dates differ by $47 \mathrm{ka}$ within a span of almost $1 \mathrm{~m}$ of sediment at around $44 \mathrm{~m}$ b.s.1. in core C2 (Table 1, Fig. 3B). Incomplete bleaching of sediment grains, owing for example to transport in murky opaque water, such as in a river with a large amount of suspended load, can result in age overestimations (e.g. Aitken 1998; Wallinga et al. 2001; Murray \& Olley 2002), which could be an explanation of the older quartz OSL ages in core $\mathrm{C} 2$ when assuming the feldspar IR-OSL ages are correct. However, Thomas et al. (2006), following investigations of mainly Weichselian sediments from Arctic Russia, including permafrost samples, ruled out partial or incomplete bleaching as a possible source for age deviations or inconsistencies within this type of sediment. Wallinga et al. (2001) reported a nearly $50 \%$ age underestimation of feldspar IR-OSL ages when compared with quartz OSL ages measured on the same samples, presumably because of anomalous fading. Supposing that the quartz OSL dates are correct, this assumption would explain the considerably younger feldspar ages in core C2 sediments.

Processes likely to be of importance to a luminescence age in permafrost environments include changing moisture contents during the time of burial, conditions associated with the aggradation of permafrost, and to a lesser degree radioactive disequilibrium of the uranium decay chain (Degering \& Krbetschek 2007; Murray et al. 2007). Variations in water content with time can influence an OSL age, because absorption of radiation by water lowers the dose rate. This influence can be estimated and corrected if the average water content over time can be reliably estimated. We used current sediment water for this correction, which may be problematic owing to uncertainties in the degree and timing of any oversaturation. Total water contents (ice+water) in the sediments far exceed porosity in Unit III, but not in Unit II, from which the OSL samples derive (Overduin et al. 2008).

The method-specific age-depth relationships shown in Fig. 7 have similar slopes with depth below sea level, in particular for both OSL methods in the lower segment of core C2 (Units I and II). The quartz OSL ages suggest that the Unit II terrestrial permafrost encountered in cores $\mathrm{C} 1$ and C3 is younger than Unit II sediments in C2. This implies that coastal erosion and/ or permafrost degradation following the transgression represented by Unit IVb in core C2 had already affected the terrestrial permafrost layer in core $\mathrm{C} 2$ that corresponds to Unit II in the other sediment cores.

\section{Conclusions}

This paper presents new marine-core sedimentological evidence that adds significantly to the hitherto terrestrial regional record obtained from exposures and surface sediments, to expand our knowledge of the late Quaternary landscape and permafrost dynamics at the westernmost edge of the non-glaciated Beringian landmass. Sedimentological data from Cape Mamontov Klyk combined with terrestrial and marine records show the geographical development of the western Laptev Sea shelf and coastal plain during the Late Pleistocene and the Holocene, governed by changes in sea level on a glacial to interglacial time scale. Repeated marine inundations of the shelf area are evident during interglacial periods and terrestrial periglacial environments are dominant during glacial and interstadial periods. Based on pollen, hydrochemical and sedimentological data, interglacial marine sediments lay at $64 \mathrm{~m}$ below sea level $12 \mathrm{~km}$ offshore. Onshore, aquatic, perhaps lacustrine, sediments of similar age suggest an Eemian coastline position similar to today's. More detailed knowledge of tectonically driven elevation changes in the region is necessary to refine this interpretation.

Acknowledgements. - We thank Dmitry Bolshiyanov of the Arctic and Antarctic Research Institute (AARI), St. Petersburg, Russia for sharing his IRSL and diatom data. We thank the Russian drilling team for their resourceful help in the field as well as W. Schneider and A. Dereviagin for their help surveying core material in the climate chamber, access to which was kindly provided by the Helmholtz German Research Centre for Geosciences (GFZ) in Potsdam, Germany. A. Eulenburg, U. Bastian and K. Hockun provided expert laboratory support. This study is part of the research project Dynamics of Permafrost (03G0589) supported by the German Ministry of Education and Research (BMBF) within the Russian-German scientific cooperation Laptev Sea System. We thank Professor Astakhov and an anonymous reviewer for improving our interpretation.

\section{References}

Aitken, M. J. 1998: An Introduction to Optical Dating. 280 pp. Oxford University Press, Oxford.

Andreev, A. A., Grosse, G., Schirrmeister, L., Kuzmina, S. A., Novenko, E. Y., Bobrov, A. A., Tarasov, P. E., Kuznetsova, T. V., Krbetschek, M., Meyer, H. \& Kunitsky, V. V. 2004: Late Saalian and Eemian palaeoenvironmental history of the Bol'shoy Lyakhovsky Island (Laptev Sea region, Arctic Siberia). Boreas 33, 319-348.

Anisimova, N. P. 1981: Cryohydrogeological Particularities of Permafrost Zone. 153 pp. Nauka, Novosibirsk (in Russian).

Bauch, H. A., Mueller-Lupp, T., Taldenkova, E., Spielhagen, R. F., Kassens, H., Grootes, P. M., Thiede, J., Heinemeier, J. \& Petryashov, V. V. 2001: Chronology of the Holocene transgression at the north Siberian margin. Global Planetary Change 31, 125-139.

Bolshiyanov, D. Y. 2006: Passive Glaciation of the Arctic and Antarctica. 295 pp. Arctic and Antarctic Research Institute (AARI), St. Petersburg (in Russian).

Bolshiyanov, D. Y. \& Molodkov, A. M. 1999: Marine Pleistocene deposits of the Taymyr peninsula and their age from ESR dating. In Kassens, H., Bauch, H. A., Dmitrenbko, I. A., Eicken, H., Hubberten, H.-W., Melles, M., Thiede, J. \& Timokhov, L. A. (eds.): 
Land-Ocean Systems in the Siberian Arctic: Dynamics and History, 469-475. Springer, Berlin.

Boyarsky, O. G. \& Mitt, K. L. 1961: Novye dannye ob iskopaemykh ldakh v tundre Anabaro-Olenekskogo mezhdurech'ya. Merzlotnye Issledovania 1, 154-162.

Brouchkov, A. 2002: Nature and distribution of frozen saline sediments on the Russian Arctic coast. Permafrost and Periglacial Processes 13, 83-90.

Brown, J., Ferrians, O. J., Heginbottom, J. A. \& Melnikov, E. S. 1998: Circum-Arctic map of permafrost and ground-ice conditions. In Parsons, M. \& Zhang, T. (eds.): International Permafrost Association Standing Committee on Data Information and Communication (comp.). Circum-polar Active-Layer Permafrost System, version 2.0., National Snow and Ice Data Center, Boulder, CO.

Chappell, J., Esat, T., McCulloch, M., Pillans, B., Omura, A., Pandolfi, J. \& Ota, Y. 1996: Reconciliation of late Quaternary sea levels derived from coral terraces at Huon Peninsula with deep sea oxygen isotope records. Earth and Planetary Science Letters 141, 227-236.

Chekanovsky, A. L. 1896: Fieldbook of the expedition at Rivers Nizhniaya Tunguska, Olenek and Lena in 1873-1875. Zapiski Imperatorskogo Russkogo Geograficheskogo obshestva po obshei geografii $X X$ (in Russian).

Degering, D. \& Krbetschek, M. R. 2007: Dating of interglacial sediments by luminescence methods. In Sirocko, F., Claussen, M., Sánchez Goñi, M. F. \& Litt, T. (eds.): The Climate of Past Interglacials. Developments in Quaternary Sciences, 7, 157-171. Elsevier, Oxford.

Drachev, S. S., Kaul, N. \& Beliaev, V. N. 2003: Eurasia spreading basin to Laptev shelf transition: structural pattern and heat flow. Geophysical Journal International 152, 688-698.

Drachev, S. S., Savostin, L. A., Groshev, V. G. \& Bruni, I. E. 1998: Structure and geology of the continental shelf of the Laptev Sea, Eastern Russian Arctic. Tectonophysics 298, 357-393.

Dumas, B., Hoang, C. T. \& Raffy, J. 2006: Record of MIS 5 sea-level highstands based on U/Th dated coral terraces of Haiti. Quaternary International 145/146, 106-118.

Faegri, K. \& Iversen, J. 1989: Textbook of Pollen Analysis. 328 pp. John Wiley \& Sons, New York.

Fartyshev, A. I. 1993: Osobennosti Pribrezhno-Shelfovoi Kriolitozony Morya Laptevykh. 136 pp. Nauka, Novosibirsk.

Franke, D., Hinz, K. \& Reichert, C. 2004: Geology of the East Siberian Sea, Russian Arctic, from seismic images: structures, evolution, and implications for the evolution of the Arctic Ocean Basin. Journal of Geophysical Research 109, B07106, doi:10.1029/ 2003JB002687.

Grigoriev, M. N. 2008: Kriomorfogenez i litodinamika priberezhnoshel'fovoi zony morei vostochnoi Sibiri. Habilitation thesis, Russian Academy of Sciences, Siberian Branch, Permafrost Institute Yakutsk, $291 \mathrm{pp}$.

Grosse, G., Schirrmeister, L. \& Malthus, T. J. 2006: Application of Landsat-7 satellite data and a DEM for the quantification of thermokarst-affected terrain types in the periglacial Lena-Anabar coastal lowland. Polar Research 25, 51-67.

Hubberten, H. -W., Andreev, A., Astakhov, V. I., Demidov, I., Dowdeswell, J. A., Henriksen, M., Hjort, C., Houmark-Nielsen, M., Jakobsson, M., Kuzmina, S., Larsen, E., Lunkka, J. P., Lysa, A., Mangerud, J., Möller, P., Saarnisto, M., Schirrmeister, L., Sher, A. V., Siegert, C., Siegert, M. J. \& Svendsen, J. I. 2004: The periglacial climate and environment in northern Eurasia during the last glaciation. Quaternary Science Reviews 23, 1333-1357.

Ilyashuk, B. P., Andreev, A. A., Bobrov, A. A., Tumskoy, V. E. \& Ilyashuk, E. A. 2006: Interglacial history of a palaeo-lake and regional environment: a multi-proxy study of a permafrost deposit from Bol'shoy Lyakhovsky Island, Arctic Siberia. Journal of Paleolimnology 35, 855-872.

Junker, R., Grigoriev, M. N. \& Kaul, N. 2008: Non-contact infrared temperature measurement in dry permafrost boreholes. Journal of Geophysical Research 113, B04102. doi: 10.1029/2007JB004946.

Katasonov, E. M. 1983: Cryolithogenic Deposits, Their Geocryological Formation Complexes: Problems of Geocryology. 169 pp. Nauka, Moscow (in Russian).

Kienast, F., Tarasov, P., Schirrmeister, L., Grosse, G. \& Andreev, A. A. 2008: Continental climate in the East Siberian Arctic during the last interglacial: implications from palaeobotanical records. Global and Planetary Change 60, 535-562.

Kind, N. V. \& Leonov, B. N. (eds.), 1982: The Anthropogene of Taimyr (Antropogen Taimyra). 184pp. Nauka, Moscow (in Russian).

Koch, K., Knoblauch, C. \& Wagner, D. 2009: Methanogenic community composition and anaerobic carbon turnover in submarine permafrost sediments of the Siberian Laptev Sea. Environmental Microbiology 11, 657-668.

Kolpakov, V. V. 1973: The paleogeographical significance of Quaternary Aeolian deposits in the north of eastern Siberia. In Ragozin, L. A. (ed.): Some Problems of Regional Geology, 38-42. Moscow University Publishing, Moscow (in Russian).

Magens, D. 2005: Late Quaternary climate and environmental history of the Siberian Arctic - permafrost records from Cape Mamontovy Klyk, Laptev Sea. M.Sc. thesis, Christian-Albrecht-University of Kiel, 141 pp.

Meyer, H., Siegert, C., Dereviagin, A. \& Hubberten, H.-W. 2002: Paleoclimatic changes in the Late Quaternary - evidences from stable isotopes of ground ice of the Bykovsky Peninsula, NE Siberia. Polarforschung 70, 37-51.

Meyers, P. A. \& Lallier-Vergés, E. 1997: Lacustrine sedimentary organic matter records of Late Quaternary paleoclimates. Journal of Paleolimnology 21, 345-372.

Meyers, P. A., Leenheer, M. J. \& Bourbonniere, R. A. 1995: Diagenesis of vascular plant organic matter components during burial in lake sediments. Aquatic Geochemistry 1, 35-52.

Molodkov, A. \& Bitinas, A. 2006: Sedimentary record and luminescence chronology of the Lateglacial and Holocene aeolian sediments in Lithuania. Boreas 35, 244-254.

Müller, S., Bobrov, A. A., Schirrmeister, L., Andreev, A. A. \& Tarasov, P. E. 2009: Testate amoebae record from the Laptev Sea coast and its implication for the reconstruction of Late Pleistocene and Holocene environments in the Arctic Siberia. Palaeogeography, Palaeoclimatology, Palaeoecology 271, 301-315.

Murray, A. S. \& Olley, J. M. 2002: Precision and accuracy in the optical stimulated luminescence dating of sedimentary quartz: a status review. Geochronometria 21, 1-16.

Murray, A. S., Svendsen, J. I., Mangerud, J. \& Astakhov, V.I. 2007: Testing the accuracy of quartz OSL dating using known-age Eemian site on the river Sula, northern Russia. Quaternary Geochronology 2, 102-109.

Nadeau, M. J., Grootes, P. M., Schleicher, M., Hasselberg, P., Rieck, A. \& Bitterling, M. 1998: Sample throughput and data quality at the Leibniz-Labor AMS facility. Radiocarbon 40, 239-245.

Nadeau, M. J., Schleicher, M., Grootes, P. M., Erlenkeuser, H., Gottdang, A., Mous, D. J. W., Sarntheim, J. M. \& Willkomm, H. 1997: The Leibniz-Labor facility at the Christian-Albrecht-University, Kiel, Germany. Nuclear Instruments and Methods 123, $22-30$.

Osterkamp, T. E. 2001: Sub-sea permafrost. In Steele, J. H., Thorpe, S. A. \& Turekian, K. K. (eds.): Encyclopedia of Ocean Sciences, 2902-2912. Academic Press, New York.

Overduin, P. P., Grigoriev, M. N., Junker, R., Rachold, V., Kunitsky, V. V., Bolshiyanov, D. Yu. \& Schirrmeister, L. 2007a: Russian-German cooperation SYSTEM LAPTEV SEA: The expedition COAST I. In Schirrmeister, L. (ed.): Expeditions in Siberia in 2005, 1-39. Reports on Polar and Marine Research, 550.

Overduin, P. P., Hubberten, H.-W., Rachold, V., Romanovkii, N. N., Grigoriev, M. \& Kasymskaya, M. 2007b: The evolution and degradation of coastal and offshore permafrost in the Laptev and East Siberian Seas during the last climatic cycle. In Harff, J., Hay, W. W. \& Tetzlaff, D. M. (eds.): Coastline Changes: Interrelation of Climate and Geological Processes, 97-111. Geological Society of America, Special Paper 426.

Overduin, P. P., Rachold, V. \& Grigoriev, M. N. 2008: The state of subsea permafrost in the western Laptev nearshore zone. In Kane, D. L. \& Hinkel, K. M. (eds.): Proceedings of the 9th International Conference on Permafrost, 1345-1350. Fairbanks, Alaska.

Puminov, A. P. 1962: Cover sediments of the Anabar-Olenek interfluve. Trudy Instituta Geologii i Geofiziki 27, 102-117.

Rachold, V., Bolshiyanov, D. Y., Grigoriev, M. N., Hubberten, H.-W., Junker, R., Kunitsky, V. V., Merker, F., Overduin, P. \& Schneider, W. 2007: Nearshore arctic subsea permafrost in 
transition. EOS Transactions American Geophysical Union 88, $149-156$

Romanovskii, N. N. 1993: Fundamentals of the Lithosphere Cryogenesis. 335 pp. Moscow State University Publishers, Moscow (in Russian).

Romanovskii, N. N. \& Hubberten, H.-W. 2001: Results of permafrost modelling of the lowlands and shelf of the Laptev Sea region, Russia. Permafrost Periglacial Processes 12, 191-202.

Romanovskii, N. N., Gavrilov, A. V., Kholodov, A. L., Pustovit, G. P., Hubberten, H.-W., Niessen, F. \& Kassens, H. 1998: Map of predicted offshore permafrost distribution on the Laptev Sea Shelf. In Lewkowizc, A. G. \& Allard, M. (eds.): 7th International Conference on Permafrost, 967-972. Yellowknife, Canada.

Romanovskii, N. N., Hubberten, H.-W., Gavrilov, A. V., Eliseeva, A A. \& Tipenko, G. S. 2005: Offshore permafrost and gas hydrate stability zone on the shelf of East Siberian Seas. Geo-Marine Letters $25,167-182$.

Romanovskii, N. N., Hubberten, H. -W., Gavrilov, A. V., Tumskoy, V. E. \& Kholodov, A. L. 2004: Permafrost of the east Siberian Arctic shelf and coastal lowlands. Quaternary Science Reviews 23, 1359-1369.

Romanovskii, N. N., Hubberten, H.-W., Gavrilov, A. V., Tumskoy, V. E., Tipenko, G. S., Grigoriev, M. N. \& Siegert, C. 2000: Thermokarst and land-ocean interactions, Laptev Sea region, Russia. Permafrost Periglacial Processes 11, 137-152.

Schirrmeister, L., Siegert, C., Kuznetsova, T., Kuzmina, S., Andreev, A. A., Kienast, F., Meyer, H. \& Bobrov, A. A. 2002: Paleoenvironmental and paleoclimatic records from permafrost deposits in the Arctic region of Northern Siberia. Quaternary International 89, 97-118.

Schirrmeister, L., Kunitsky, V. V., Grosse, G., Schwamborn, G., Andreev, A. A., Meyer, H., Kuznetsova, T., Bobrov, A. \& Oezen, D. 2003: Late Quaternary history of the accumulation plain north of the Chekanovsky Ridge (Lena Delta, Russia) - a multidisciplinary approach. Polar Geography 27, 277-319.

Schirrmeister, L., Grigoriev, M. N., Kutzbach, L., Wagner, D. \& Bolshiyanov, D. Y. 2004: Russian-German cooperation SYSTEM LAPTEV SEA: The expedition Lena-Anabar 2003, 1-210. Reports on Polar and Marine Research 489.

Schirrmeister, L., Grosse, G., Kunitsky, V., Magens, D., Meyer, H., Dereviagin, A., Kuznetsova, T., Andreev, A., Babiy, O., Kienast, F., Grigoriev, M. N., Overduin, P. P. \& Preusser, F. 2008: Periglacial landscape evolution and environmental changes of Arctic lowland areas for the last 60,000 years (western Laptev Sea coast, Cape Mamontov Klyk). Polar Research 27, 249-272.

Sher, A. V., Kuzmina, S. A., Kuznetsova, T. V. \& Sulerzhitsky, L. D. 2005: New insights into the Weichselian environment and climate of the East Siberian Arctic, derived from fossil insects, plants, and mammals. Quaternary Science Reviews 24, 533-569.

Siegert, C., Schirrmeister, L. \& Babiy, O. 2002: The sedimentologieal, mineralogical and geochemical composition of late Pleistocene deposits from the lce Complex on the Bykovsky Peninsula, Northern Siberia. Polarforschung 70, 3-11.
Sochava, V. B. 1933: Tundras of the Anabar River basin. Izvestiva Gosudarstvennogo Geograficheskogo Obshestva 65, 341-364.

Stead, R. A. \& Thompson, R. J. 2003: Physiological energetics of the protobranch bivalve Yoldia hyperborea in a cold ocean environment. Polar Biology 26, 71-78.

Stuiver, M. \& Pollach, H. A. 1977: Discussion: Reporting of 14C data. Radiocarbon 19, 335-363.

Svendsen, J. I., Alexanderson, H. \& Astakhov, V. I. et al. 2004: Late Quaternary ice-sheet history of northern Eurasia. Quaternary Science Reviews 23, 1229-1271.

Thomas, P. J., Murray, A. S., Kjær, K. H., Funder, S. \& Larsen, E. 2006: Optically Stimulated Luminescence (OSL) dating of glacial sediments from Arctic Russia - depositional bleaching and methodological aspects. Boreas 35, 587-599.

Toll, E. V. 1894: The expedition of Imperial Academy of Science in 1893 to the New Siberian Islands and coast of the Ice Ocean. Izvestiya Imperatorskogo Russkogo Geograficheskogo Obshestva 30, 435-451.

Tolmachev, I. P. 1905: New findings on Siberia's geology. Trudy Petersburgskogo Obshestva Estestvoispytateley. 24(1).

Van Everdingen, R. O. (ed.), 1998: Multi-language Glossary of Permafrost and Related Ground-Ice Terms. 230 pp. National Snow and Ice Data Center/World Data Center for Glaciology, Boulder, CO.

Wallinga, J., Murray, A. S., Duller, G. A. T. \& Törnqvist, T. E. 2001: Testing optically stimulated luminescence dating of sand-sized quartz and feldspar from fluvial deposits. Earth and Planetary Science Letters 193, 617-630.

Wetterich, S., Kuzmina, S., Andreev, A. A., Kienast, F., Meyer, H., Schirrmeister, L., Kuznetsova, T. \& Sierralta, M. 2008: Palaeoenvironmental dynamics inferred from late Quaternary permafrost deposits on Kurungnakh Island (Lena Delta, Northeast Siberia, Russia). Quaternary Science Reviews 27, 1523-1540

Wetterich, S., Schirrmeister, L., Andreev, A. A., Pudenz, M., Plessen, B., Meyer, H. \& Kunitsky, V. V. 2009: Eemian and Late Glacial/ Holocene palaeoenvironmental records from permafrost sequences at the Dmitry Laptev Strait (NE Siberia, Russia). Palaeogeography, Palaeoclimatology, Palaeoecology 279, 73-95.

Winterfeld, M. 2009: Characterisation of terrestrial permafrost affected by inundation and Late Quaternary landscape evolution (Western Laptev Sea, Siberia). M.Sc. thesis, Ernst Moritz Arndt University Greifswald, 199 pp.

Wintle, A. G. 1997: Luminescence dating: laboratory procedures and protocols. Radiation Measurements 27, 769-817.

Zhang, T., Barry, R. G., Knowles, K., Heginbottom, J. A. \& Brown, J. 1999: Statistics and characteristics of permafrost and ground ice distribution in the Northern Hemisphere. Polar Geography 23, 132-154.

Zhigarev, L. A. 1997: Okeanicheskaya Kriolitozona. 320 pp. Moscow State University Publishers, Moscow.

Zhukov, V. V., Gorina, I. F. \& Pinchuk, L. Y. 1968: Cenozoic Diamondiferous Placer Deposits of the Anabar-Olenek Interfluve, 144 pp. Nedra, Moscow (in Russian).

Zimov, S.A, Schuur, E. A. G. \& Chapin III, F. S. 2006: Permafrost and the global carbon budget. Science 312, 1612-1613.

Correction added after online publication February 2011: a new sentence was added to the beginning of the Acknowledgement section. 